\title{
Entre Senegâmbia e Angola: COMÉRCIO ATLÂNTICO, PROTAGONISMO AFRICANO E DINÂMICAS REGIONAIS (SÉCULOS XVII E XIX)*
}

\author{
Felipe Silveira de Oliveira Malacco (D) \\ Universidade Federal de Minas Gerais
}

Ivan Sicca Gonçalves (D)

Universidade Estadual de Campinas

conexão da costa africana com as rotas comerciais do nascente
Mundo Atlântico, a partir do século XV, trouxe profundas trans-
formações políticas, econômicas, sociais e culturais a milhões de africanos e africanas que habitavam nessas regiões, para além dos mais de doze milhões que foram brutalmente escravizados e levados para as Américas. Para além do litoral, as diversas sociedades africanas que se conectaram com o comércio atlântico na Era Moderna, que não se resumia ao tráfico de escravizados, também testemunharam radicais transformações no interior do continente. Para refletir sobre esses processos históricos, o presente texto propõe discutir o funcionamento do comércio de longa distância no interior de duas regiões que foram profundamente integradas às malhas do comércio atlântico - a Senegâmbia e a Angola Central em dois momentos de reconfiguração econômica dessas macrorregiões ligados a mudanças no comércio oceânico: a intensificação do contato dos

* Este texto surgiu a partir de encontros e inquietações comuns dos dois autores em diversos congressos ocorridos nos anos de 2018 e 2019. Agradecemos aos organizadores desses eventos, assim como aos seus participantes. Agradecemos também ao colega Talison Picheli pelas sugestões bibliográficas e aos dois pareceristas anônimos pelas sugestões, comentários e críticas ao texto. 
povos da Senegâmbia com o comércio atlântico nos séculos XVI e XVII e as novas demandas por gêneros coloniais de Angola em meados do XIX, após a proibição legal do tráfico atlântico de escravizados.

Pretendemos, a partir dessas duas incursões, defender duas proposições analíticas que consideramos fundamentais para pensar o comércio interno em regiões africanas conectadas ao Mundo Atlântico. Inicialmente, que há uma inquestionável autonomia histórica do comércio africano. Mesmo alimentando as demandas europeias com vultuosas quantidades de escravizados, assim como outras mercadorias importantes como marfim, metais, pedras preciosas, commodities agrícolas, entre outros, esse comércio não se resumia a atender os interesses dos comerciantes europeus e americanos que, na maior parte das vezes, não saíam das regiões costeiras. Tais atividades não só envolviam várias rotas e demandas internas que eram independentes das demandas oceânicas, como, mesmo nos circuitos que se transformaram mais radicalmente por causa da interferência dos agentes do atlântico, as demandas históricas de agentes do interior do continente continuaram sendo atendidas. Como demonstraremos, mesmo em regiões do continente em que houve presença e ocupação militar europeia, como o caso de Angola, as pressões do comércio oceânico podem ter sido mais intensas, mas não suplantaram as dinâmicas e demandas dos povos do interior.

Além disso, entendemos ser fundamental destacar o protagonismo dos agentes africanos, mesmo nas regiões geralmente tidas como subjugadas a um suposto domínio europeu. Não só o controle político e militar da gigantesca maioria das regiões africanas conectadas ao atlântico era realizado por mandatários africanos, incluindo muitos dos ditos enclaves europeus na costa, como também os termos do comércio que alimentava tais demandas oceânicas eram, via de regra, controlados por mandatários africanos que interferiam diretamente no cotidiano das decisões comerciais. Assim, os agentes africanos ligados às atividades comerciais no interior do continente não eram só protagonistas desse comércio, decidindo valores, como e com quem fazer as trocas, mas, 
consequentemente, suas escolhas e estratégias impactavam diretamente o funcionamento de toda a rede atlântica.

O contraste que propomos entre o interior do continente e a costa atlântica vai além de termos meramente físicos. Levando em conta que as categorias geográficas são produtos das relações que os homens desenvolvem com os espaços, consideramos que, assim como o entendimento do Atlântico como um único oceano - e não uma série de mares distintos é uma construção histórica, a separação do litoral deste oceano frente às regiões contíguas a ele no interior também o é. ${ }^{1}$ Vale destacar que antes da integração comercial entre as quatro margens do Atlântico, os mandatários africanos e seus comerciantes não viam o oceano como uma potencial saída de rotas comerciais, orientando geralmente a sua atenção, portanto, às rotas que iam para o interior do continente. Assim pode-se dizer que as preocupações dessas lideranças da costa atlântica estavam figurativamente “de costas para o mar”, sendo que os povos litorâneos estavam localizados na periferia dos principais circuitos comerciais. ${ }^{2}$

Além disso, a integração histórica entre o litoral atlântico e o interior do continente africano passou por recriações por parte de narrativas historiográficas. No caso das regiões em que nos deteremos na sequência, como apontou Alfredo Margarido em ensaio de 1989, muitos historiadores que se dedicaram a estudar o Império Português em períodos anteriores ao século XX alimentaram uma ficção de um domínio nominal sobre territórios do continente africano para justificar uma suposta continuidade entre essas presenças portuguesas na Era Moderna e o colonialismo consolidado no século XX. Essas narrativas, que alimentavam o discurso de autoafirmação do domínio colonial luso que durou até 1975, supunham

1 Alison Games, “Atlantic History: Definitions, Challenges, and Opportunities”, The American Historical Review, v. 111, n. 3 (2006), pp. 742-743; David Armitage, "Three Concepts of Atlantic History" in David Armitage e Michael J. Braddick (orgs.), The British Atlantic World, 1500-1800, (Nova York: Palgrave Macmillan, 2002), pp. 11-12. Há uma versão traduzida deste texto para o português: "Três conceitos de história atlântica”, História Unisinos, v. 18, n. 2 (2014), pp. 206-217.

2 Estevam C. Thompson, “O Atlântico Sul para além da miragem de um espaço homogêneo (séculos XV-XIX)”, Temporalidades, v. 4, n. 2 (2012), p. 81. 
relações de domínio sobre regiões e soberanos africanos que na realidade eram autônomos diante dos interesses dos portugueses. ${ }^{3}$

Por outro lado, além dessa suposição de um controle político extemporâneo, por vezes a historiografia de ambas as regiões dedicou uma ênfase superestimada no protagonismo comercial dos grupos geralmente tidos como euro-africanos ou luso-africanos. Tais trabalhos muitas vezes entenderam esses agentes como pioneiros de uma interiorização da zona de influência cultural e econômica dos “impérios ultramarinos” europeus. ${ }^{4}$ Como já apontado no clássico estudo de Philip Curtin sobre as chamadas diásporas comerciais, que consistiram no deslocamento geográfico de negociantes para áreas de culturas e identidades distintas, uma das mais importantes variáveis de análise é a relação dos comerciantes com as sociedades hospedeiras, sendo inviável entender a história da atuação desses euro-africanos sem compreender o quanto os seus hospedeiros controlavam política e economicamente os seus espaços de atuação. ${ }^{5}$ Além disso, como detalharemos ao longo do texto, por vezes a ênfase nos intermediários de origem europeia intensificou uma miopia na percepção de diversas outras diásporas comerciais intra-africanas simultâneas que controlavam complexas redes do comércio interiorano. ${ }^{6}$

3 Alfredo Margarido, “Algumas formas da hegemonia africana nas relações com os europeus” in Maria Emília Madeira Santos (org.), Actas da 1. ${ }^{a}$ RIHA - Relação Europa-África no 3. ${ }^{\circ}$ Quartel do Século XIX (Lisboa: Instituto de Investigação Científica Tropical, 1989), pp. 383-385. Para mais sobre essa historiografia, ver: Isabel Castro Henriques, Percursos da modernidade em Angola: dinâmicas comerciais e transformações sociais no século XIX, Lisboa: Instituto de Investigação Científica Tropical, 1997, pp. 83-104.

4 Para a Senegâmbia, ver, por exemplo: Maria João Soares, "Para uma compreensão dos lançados nos Rios da Guiné: Século XVI - Meados do Século XVII”, Revista Stvdia, n. 56-57 (2000). Para Angola, ver: Jean-Luc Vellut, "Notes sur le Lunda et la frontière luso-africaine (1700-1900)”, Études d'Histoire africaine, v. 3, (1972), pp. 140-145.

5 Philip D. Curtin, Cross-cultural trade in world history, Cambridge: Cambridge University Press, 1984, pp. 5-6.

6 Outra crítica recente para a ênfase da historiografia nas chamadas luso-africanidades pode ser vista em: Alec Ichiro Ito, “Usos, reusos e abusos: atravessando ‘fronteiras’ e 'luso-africanidades’ nas historiografias de Angola, Cabo Verde e Guiné-Bissau para os séculos XV, XVI e XVII”, Revista Brasileira de Estudos Africanos, v. 4, n. 8 (2019), pp. 115-134. 
Tendo em vista tais tendências, acreditamos ser profícuo o diálogo com o campo de estudos da História Atlântica, que hoje conta com intensa notoriedade no campo dos estudos históricos ao possibilitar análises comparadas e conectadas de diversas regiões que estiveram ligadas às dinâmicas históricas desse oceano. Acreditamos que, para além de modismos acadêmicos, entender essas regiões africanas por suas ligações com o Atlântico é uma possibilidade de abordar suas histórias de forma menos enviesada do que as propostas imperiais, pensando conexões com um espaço histórico mais neutro que não é sinônimo de um suposto domínio multissecular. ${ }^{7}$

Mesmo não se tratando de regiões contíguas ao oceano, com os processos de formação do Mundo Atlântico diversos territórios do interior se integraram em rotas de longa distância, pelas quais passavam pessoas e mercadorias, e junto com elas notícias, ideias e culturas, formando o que se chama de zonas atlânticas, que ao longo dos séculos da Era Moderna avançaram por centenas de quilômetros rumo ao centro do continente. No entanto, para compreender a formação e as transformações políticas, econômicas e sociais dessas zonas, é fundamental reconhecer que elas não se constituíram em territórios e sociedades desprovidos de história, sendo, portanto, formadas de acordo com as dinâmicas sociais e comerciais preexistentes em muitas regiões em que o comércio de longa distância já se desenvolvia séculos antes dos primeiros contatos com os europeus na costa. ${ }^{8}$

Não minimizando, portanto, a autonomia histórica das sociedades do interior do continente, abordaremos essas regiões em função das suas conexões com o Atlântico para entendermos melhor as transformações

7 Games, “Atlantic History”, pp. 743-745.

8 Ao contrário das regiões que margeiam o deserto do Saara, já houve autores como Jan Vansina que chegaram a afirmar que no caso da África Central não existiam rotas de longa distância até a chegada dos europeus no litoral, resumindo-se o comércio no interior a rotas regionais. Ver: Jan Vansina, "Long-Distance Trade-Routes in Central Africa”, The Journal of African History, v. 3, n. 3 (1962), pp. 376-377. Para uma crítica a essa abordagem, ver: Henriques, Percursos da modernidade em Angola, pp. 380-382. 
que tais vínculos fomentavam, assim como o quanto os agentes dessas regiões também influenciavam nas redes atlânticas. Seguindo, portanto, a proposta da historiadora Alison Games, defendemos o uso da abordagem da História Atlântica, pois:

Essas sociedades [focalizadas pela História Atlântica] não são necessariamente lugares ao longo do Oceano Atlântico em si [...] E nem a História Atlântica é somente sobre os pontos literalmente de contato (portos, comerciantes ou migrantes, por exemplo), e sim sobre explicar transformações, experiências e eventos em um lugar em termos das condições derivadas pela localização desse lugar em um mundo mais amplo, multifacetado e interconectado. ${ }^{9}$

Para entender essas dinâmicas históricas, usaremos como fontes principais desse estudo documentos escritos por europeus ou por homens que se representavam enquanto tais. Com objetivos e meios de circulações diferentes, em geral esses documentos possuem muitas informações descritivas sobre as populações africanas envolvidas no comércio interno. É fundamental entender que tais autores reproduzem acima de tudo representações sobre os africanos, com mediações, filtros, limites e bases culturais que devem ser considerados pelos historiadores que lidam com essa documentação. No entanto, nosso objetivo não é o de estudar as representações de africanos em relatos europeus, e sim estudar as dinâmicas sociais que esses europeus testemunham e nas quais muitas vezes se inserem, em um esforço de decodificação e recodificação que leva em conta esses filtros culturais da fonte, assim como a própria narrativa dos africanos que servem de informantes para tais escritores europeus. ${ }^{10}$

9 Games, “Atlantic History”, p. 747.

10 José da Silva Horta, "Entre história europeia e história africana, um objeto de charneira: as representações” in José da Silva Horta (org.), Actas do Colóquio Construção e Ensino da história da África (Lisboa: Linopazes, 1995), pp. 189-200. 
Seguindo a proposta de Elaine Ribeiro, entendemos principalmente ser possível perceber as vozes africanas nesses documentos por meio do que chamou de interstícios do discurso colonial. Ribeiro, ao estudar o relato da viagem do major português Henrique Augusto Dias de Carvalho para o Império da Lunda, no nordeste da atual Angola, percebe que ao fazer registros cotidianos da expedição, para conseguir compreender os território e povos visitados, o major teve que reconhecer a agência dos sujeitos africanos, assinalando, além dos seus objetivos políticos e científicos iniciais, os interesses e lógicas das populações locais. Além disso, a historiadora mostrou no mesmo trabalho que por esses interstícios também acabavam aparecendo, no meio das narrativas de dominação, os próprios africanos que acompanhavam os viajantes, com fragmentos de suas vidas, desejos e trajetórias. ${ }^{11}$

Para a região da Senegâmbia nossas fontes serão documentos de diferentes tipologias, escritos por agentes europeus e cabo-verdianos: cartas de missionários, documentação oficial de Cabo Verde ${ }^{12}$ e relatos de viagens - terminologia que, por si só, é insuficiente ${ }^{13}$ - escritos entre 1580 e 1700. Os relatos de viagens foram escritos por comerciantes de diferentes nacionalidades europeias - portugueses, franceses, ingleses, germânicos, flamengos - e por pessoas que nasceram no arquipélago de Cabo Verde, mas que se entendiam enquanto portuguesas. As outras tipologias documentais foram recolhidas na Monumenta Missionaria Africana, obra do Padre Antônio Brásio, disponível em CD-ROM, coligida e anotada pelo religioso entre 1952 e 2004. O autor pretendia agregar numa única

11 Elaine Ribeiro, Barganhando sobrevivências: os trabalhadores da expedição de Henrique de Carvalho à Lunda, São Paulo: Alameda, 2013, pp. 95-138.

12 Como, por exemplo, cartas de governadores e capitães de Cabo Verde. Ver: "Regimento do Capitão de Cacheu Rio Grande e de S. Domingos [11 out. 1625]" in António Brásio, Monumenta Missionária Africana (Lisboa: Agência Geral do Ultramar, 1952), v. IV, pp. 85-89; e "Regimento do Capitão da Guiné [4 abr. 1615]" in Brásio, Monumenta, v . IV, pp. 573-576.

13 Dentro do mesmo léxico são enquadradas inúmeras formas de escritos de viajantes, como diários, crônicas e memoriais, que variavam de acordo com a forma e com a própria intencionalidade do autor com seus escritos. 
obra documentos que ele selecionou como os mais relevantes sobre a ação missionária e eclesiástica em África. ${ }^{14}$

No caso de Angola, focalizaremos especificamente na região do Planalto Central, onde se localizavam grandes Estados centro-africanos como o Bié e o Bailundo, sendo importante região tanto no fornecimento de cativos para o litoral, quanto na conexão de rotas de longa distância para regiões ainda mais distantes da costa, como o Alto Zambeze, a bacia do rio Kasai e o Barotse. Como fonte principal, utilizaremos os cadernos do comerciante António Francisco Ferreira da Silva Porto, nascido no Porto em 1817, que residiu a partir de 1841 no interior de Angola, na corte do reino do Bié, onde viveu por toda a vida, até seu suicídio em 1890. Silva Porto durante quase todo esse período de residência no interior alimentou um diário, no qual relatava acontecimentos cotidianos e fazia apontamentos sobre os povos do interior, seus costumes e suas riquezas, desejando assim contribuir para a formação de um saber colonial. Para tal, enviou seus diários para correspondentes da metrópole, sendo os primeiros cinco volumes, que relatam o período entre 1846 e 1869, a documentação principal a ser explorada. ${ }^{15}$

Ao abordarmos essas fontes procurando destacar o protagonismo dos agentes africanos no controle dessas rotas do comércio interno, aproximamos o foco e percebemos uma imensa diversidade de produtos

14 É composta por vinte e dois volumes divididos em duas séries. A primeira, constituída por 15 volumes, diz respeito à área geográfica abrangida pela primitiva diocese de S. Tomé, do rio de André, ao sul do Cabo das Palmas, até o Cabo das Agulhas. A segunda série é composta por sete volumes referentes ao território da diocese de Cabo Verde, desde o rio Gâmbia até o Cabo das Palmas, compreendendo assim toda a Costa Ocidental Africana, ao sul da atual República da Gâmbia.

15 Sobre a vida e obra de Silva Porto, ver: Maria Emília Madeira Santos, "Introdução (Trajectória do Comércio do Bié)” in Viagens e apontamentos de um portuense em África: diário de António Francisco Ferreira da Silva Porto (Coimbra: Biblioteca Geral da Universidade de Coimbra, 1986), v. 1, pp. 13-216; Constança do Nascimento da Rosa Ferreira de Ceita Miguel, “A vida e a obra do portuense Silva Porto no Reino Ovimbundu, Bié (1839-1890)”, Dissertação (Mestrado), Faculdade de Letras da Universidade do Porto, Porto, 2001; e "Silva Porto na África Central - Viye/Angola: história social e transcultural de um sertanejo (1839-1890)”, Tese (Doutorado), Universidade Nova de Lisboa, Lisboa, 2014. 
envolvidos nas várias modalidades de trocas realizadas entre os diversos agentes do interior. Como já apontou Mariza de Carvalho Soares, a pungente historiografia sobre o comércio atlântico de escravizados acabou ofuscando o comércio de outras mercadorias, que passavam por circuitos regionais ou mesmo em outras etapas que não a entrega final dos contingentes de cativos para os negreiros. ${ }^{16}$ Como mostraremos ao longo desse texto, sem minimizar o impacto econômico e humano do comércio de pessoas, quando observamos o funcionamento interno de todo o processo comercial, das distantes regiões produtoras até as águas do Oceano, é impossível compreender essas malhas sem se deter sobre os vários produtos que estão circulando pelo interior do continente.

Ao propormos essa análise conjunta de duas regiões distanciadas no espaço e no recorte temporal, e com poucas conexões históricas diretas, acreditamos que nossos esforços de pesquisa para analisar os agentes africanos do comércio interno levam a questões análogas, além de enfrentarem tradições interpretativas em comum. Mesmo que não consideremos este texto como um esforço sistemático de história comparada, entendemos que essa proposta metodológica traz importantes ganhos interpretativos para o que pretendemos demonstrar. Além de destacar semelhanças e diferenças fundamentais para a compreensão de tais fenômenos históricos, a comparação permite mensurar e debater impactos e relações de causalidade nos pontos em comum entre os dois processos históricos estudados, o que, nesse caso, seria principalmente o contato com o comércio atlântico. ${ }^{17}$

16 Mariza de Carvalho Soares, “'Por conto e peso’: o comércio de marfim no Congo e Loango, séculos XV - XVII”, Anais do Museu Paulista, v. 25, n. 1 (2017), p. 61, 78. Em outro texto recente, Soares demonstrou a possibilidade de questionar interpretações consolidadas sobre o comércio interno da região da Costa da Mina a partir do estudo de cultura material presente em coleções museológicas. Ver: Mariza de Carvalho Soares, “O comércio dos Wangara e as mantas mandês no Daomé (1810)", AbeÁfrica: Revista da Associação Brasileira de Estudos Africanos, v. 1, n. 1 (2018), pp. 15-40.

17 Neyde Theml e Regina Maria da Cunha Bustamante, "História Comparada: olhares plurais”, Revista de História Comparada, v. 1, n. 1 (2007), pp. 3-4, 15; Jürgen Kocka, "Para além da comparação”, Revista Esboços, v. 21, n. 31 (2014), pp. 280-281; George M. Fredrickson, "From Exceptionalism to Variability: Recent Developments in Cross-National Comparative History”, The Journal of American History, v. 82, n. 2 (1995), pp. 587-589. 
Assim, ao colocarmos de forma comparada os momentos de reconfiguração política e econômica ligados ao redimensionamento da conexão da Senegâmbia e de Angola com o Mundo Atlântico, reconhecemos as profundas diferenças entre essas duas experiências históricas, e nos somamos aos esforços de muitos historiadores de negar que as conexões atlânticas poderiam tender à construção de uma uniformidade histórica, ou uma homogeneidade cultural. ${ }^{18}$ Na realidade, reconhecer a autonomia histórica dos povos africanos é um esforço de não só mostrar as estruturas sociais que não surgiram e nem foram completamente transformadas pelas conexões oceânicas, mas também de poder entender melhor quais foram os verdadeiros impactos dessas novas conexões. Nesse sentido, afirmou Toby Green que:

Não havia apenas um comércio atlântico, mas muitos comércios causando diferentes efeitos, e de fato a capacidade africana de influenciar o incipiente Atlântico emerge dessa diversidade de relações euro-africanas. Análises detalhadas do desenvolvimento do comércio em um contexto particular podem nos ajudar a lembrar da necessidade de deferirmos nosso entendimento, e não cair na armadilha da generalização. ${ }^{19}$

Dessa forma, a aproximação do foco para os agentes do cotidiano do comércio, sejam eles mandatários africanos, comerciantes dos povos mais envolvidos nas redes de longa distância ou mesmo comerciantes euro-africanos, é uma estratégia que, ao mesmo tempo em que permite pensar questões analíticas análogas, contribui para evitar generalizações. Por consequência, para realizar balanços mais sistemáticos do impacto desses agentes do interior no comércio atlântico como um todo, acreditamos serem necessários cada vez mais estudos regionais sobre os territórios que estiveram envolvidos na formação desses circuitos intercontinentais.

18 Games, “Atlantic History”, p. 741-743, 748-751; Thompson, “O Atlântico Sul”.

19 Toby Green, The rise of trans-Atlantic slave trade in western Africa, 1300-1589, Nova York: Cambridge University Press, 2011, p. 14. 


\section{Complementariedade comercial na Senegâmbia: comércio interno e de longa distância}

A macrorregião conhecida por Senegâmbia tem por limites geográficos o Futa Toro e o Futa Djalon a leste; o Atlântico a oeste; a região de Serra Leoa ao sul; e o rio Senegal ao norte. A unidade analítica deste espaço se dá pelo fato de se configurar como um espaço comum, em sentidos culturais, sociais e econômicos, com funcionamento articulado, que deve ser compreendido como um espaço de "conveniência e convivência” e de “complementaridade e transição”. ${ }^{20}$

Mapa 1

Oeste Africano $^{21}$

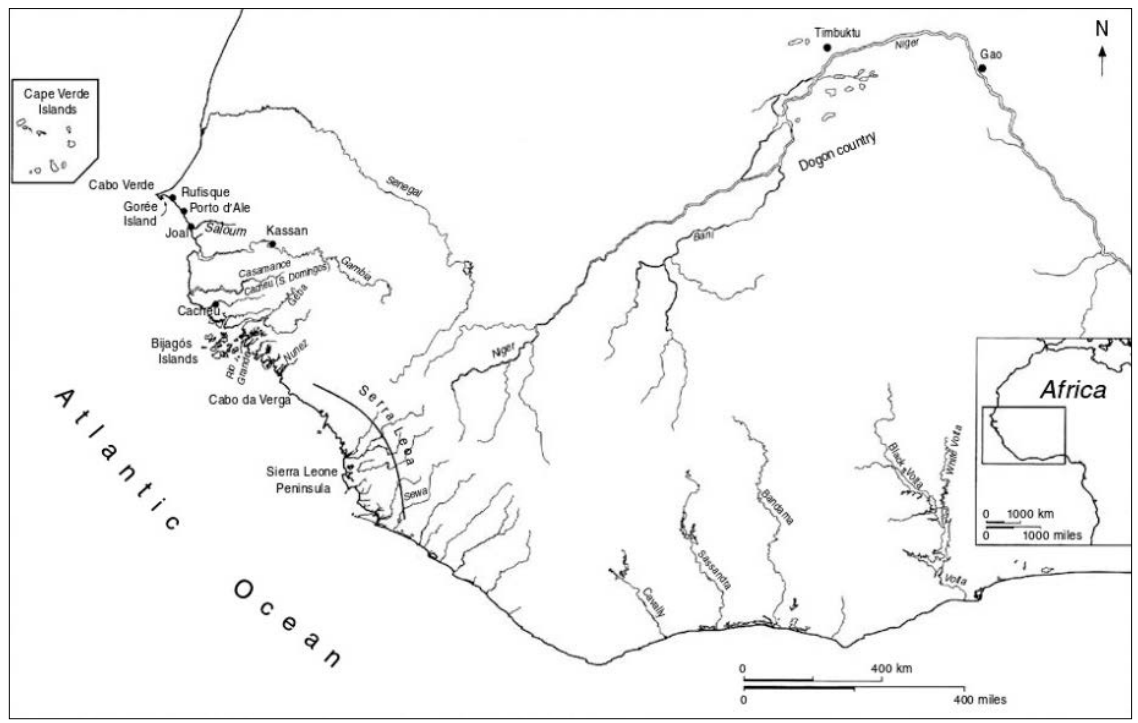

20 Eduardo Costa Dias e José da Silva Horta, “La Sénégambie: un concept historique et socioculturel et un object d'étude réevalués”, Mande Studies, n. 9 (2007).

21 Peter Mark e José da Silva Horta, The Forgotten Diaspora: Jewish Communities in West Africa and the Making of the Atlantic World, Cambridge: Cambridge University Press, 2011, p. 6. 
Dentre os vários fatores que tornam possível pensar em uma unidade senegambiana, destacamos a prática social, cultural, política e econômica de landlord and strangers reciprocities. Este conceito, definido pelo historiador estadunidense George Brooks, diz respeito à prática conformadora do tecido social senegambiano de se acolher bem os estrangeiros e tratá-los como hóspedes, ficando por parte do hospedeiro a garantia de alimentação, abrigo e proteção. Em troca, os mandatários e comerciantes locais se beneficiavam de presentes e impostos pagos pelos estrangeiros, além da possibilidade de se fazer alianças comerciais e políticas com as estruturas de mando do local de origem do hóspede e de compartilhar os lucros do comércio. ${ }^{22}$

De fato, ao procurarmos um conceito interno de organização social na Senegâmbia, pensamos ser necessário ir além de definições estrangeiras, que buscam definir espaços em África por estruturas que são externas às sociedades autóctones. Concordamos com o argumento proposto por Manuel Bivar, que afirma que "quem olhou para a Senegâmbia em busca de cimentos encontrou-os externos. Mandé, brancos, e Islão”. ${ }^{23}$ Além disso, também concordamos com o autor na medida em que complementa afirmando que "na bibliografia senegambiana as relações entre o estrangeiro e os donos da terra têm sido chamadas de landlord-stranger. Se há cimentos senegambianos este parece ser um deles”. ${ }^{24}$

Além desta prática social, havia rotas comerciais que percorriam toda essa região. Na segunda metade do século XVII, ao descrever redes comerciais que "partiam da terra do Mandimansa", região avançada

22 Para mais, ver: George Brooks, Landlords \& Strangers: Ecology, Society, and Trade in Western Africa, 1000-1630, Colorado: Westview Press, 1993; e Eurafricans in Western Africa: Commerce, Social Status, Gender, and Religious Observance from the Sixteenth to the Eighteenth Century, Athens: Ohio University Press, 2003.

23 Manuel Bivar, “Kaabu, história de um império do início ao fim”, Tese (Doutorado), Universidade Estadual de Campinas, Campinas, 2018, p. 13.

24 Bivar, “Kaabu”, p. 12. 
à leste, no sentido do interior do continente, ${ }^{25}$ o comerciante Francisco Lemos Coelho descreve o seguinte cenário:

No outro braço do rio [Pongo, na região de Serra Leoa] está a aldeia Depomga, que é do mesmo trato e negócio, nela houve também sempre aldeia de brancos, com uma Igreja de Santo Antônio, de que são muito devotos como já tenho dito; há grande negócio de marfim, e roupa branca, que chamam catés. Também há algum ouro que trazem os Jagamcazes [Jaxanke], que vem a buscar sal, porque aqui é a maior feira que tem os brancos deste gênero, e sempre o muito é pouco, estes jagamcazes dizem que quando partem da sua terra, partem três cáfilas, uma para o rio Senegal, outra para o rio Gambia e outra para aqui. ${ }^{26}$

Esta citação de Coelho evidencia outro fator que nos permite inferir a "complementaridade e transição" descrita por Dias e Horta. Os jaxankes eram um grupo de comerciantes envolvidos no comércio interno. ${ }^{27}$ Partindo do Futa Djalon, em três diferentes cáfilas, estes agentes iam comercializar no rio Pongo, Gâmbia e Senegal em rotas comerciais internas que, indo até os portos fluviais destes rios, os colocavam em contato com as redes comerciais atlânticas.

Além disso, é dessa região de Serra Leoa que era exportada a noz de cola, uma fruta que não era de importância apenas para o comércio interno

25 Diz respeito ao antigo mandatário do Mali. No período em que Lemos Coelho produziu seu relato, o poder central do Mali já havia entrado em decadência. Os mandinga, povo do Mali, passaram a ter como principal Estado o Kaabu, cujas fronteiras a leste tocavam o Futa Djalon.

26 Francisco Coelho, Duas descrições seiscentistas de Guiné, Lisboa: Academia de História Portuguesa, [1669-1684] 1953, p. 61.

27 Os jaxanke eram um grupo de comerciantes com ascendência naqueles que a historiografia trata por soninké, que passaram por um processo que os tornou próximos, em sentido político, social e cultural, aos mandingas. Partindo de Massina, no atual Mali, eles se espalharam na Senegâmbia entre os séculos XIII e XVII. Além do comércio, entre os jaxanke havia a perspectiva da criação de escolas corânicas para formação e disseminação da religião. Para mais, ver: Lamin Sanneh, The Jakhanke: the Story of an Islamic Clerical People of the Senegambia, Londres: International African Institute, 1979; e Beyond Jihad: The Pacifist Tradition in West African Islam, Nova York: Oxford University Press, 2016. 
na Senegâmbia, mas também no comércio transaariano, cujas franjas alcançavam o Futa Toro, dando aí um sentido de circulação comercial que percorria todo o espaço senegambiano. De fato, o comércio de noz de cola na região remonta ao século XIII, com importante participação dos jaxanke ${ }^{28}$ não sendo dominado exclusivamente por nenhum "grupo étnico" em específico, mesmo que tivesse proeminência entre os grupos associados aos mandingas. ${ }^{29}$ A importância da fruta era tal que o historiador Toby Green defende que a troca de nozes de cola foi um dos atributos fundamentais das práticas culturais na região da Grande Senegâmbia. ${ }^{30}$

A partir deste exemplo da noz de cola, inferimos que, para além das Landlord and Strangers Reciprocities, as vastas rotas comerciais que interligavam este espaço internamente também podem ser consideradas como um dos “cimentos” internos que conformavam a Senegâmbia.

A Senegâmbia era habitada por diversos povos. As formas de organização política oscilavam entre Estados com organização centralizada como oKaabu habitado pormandingas-, “confederações”, cujos laços políticos foram diminuindo até se quebrar pelo advento do comércio Atlântico caso dos Estados dos jalofos -, ou organizados sem centralização - como os bijagós do arquipélago ao fim do rio Geba. ${ }^{31}$ Os povos que são descritos de maneira mais recorrente nas fontes, no sentido do rio Senegal até a região de Serra Leoa são: jalofos, fulas, sereres, mandingas, arriatas, falupos, banhuns, casangas, papeis, balantas, beafares, bijagós e os sapes.

28 Paul Lovejoy, "Kola in the History of Western Africa”, Cahiers d'études africaines, v. 20, n. 78 (1980), p. 111.

29 Allen Howard, "Mande Kola Traders of Nortwestern Sierra Leone, Late 1700s to 1930”, Mande Studies, v. 9, (2007), p. 87.

30 Toby Green, A Fistfull of Sheels: West Africa from the Rise of the Slave Trade to the Age of Revolution, Chicago: The University of Chicago Press, 2019, p. 106.

31 A organização política na Senegâmbia foi tema de inúmeras pesquisas. Para mais, ver: Carlos Lopes, Kaabunké: espaço, território e poder na Guiné-Bissau, Gâmbia e Casamance pré-coloniais, Lisboa: Comissão Nacional para as Comemorações dos Descobrimentos Portugueses, 1999; Boubacar Barry, Senegambia and the Atlantic Slave Trade, Cambridge: Cambridge University Press, 2002; Jean Boulegue, Les royaumes wolof dans l'espace sénégambien (XIIIe-XVIIIe siècle), Paris: Karthala, 2013; Bivar, "Kaabu”. 
Estes povos viviam em uma macrorregião cujas características geomorfológicas principais são os numerosos cursos d’água e o fato de que existiam diferentes domínios morfoclimáticos. Ao norte do rio Gâmbia a predominância era do clima e vegetação de savana, enquanto ao sul predominam os manguezais e a floresta tropical. Dessa forma, por razões naturais, o que se produzia em uma área era diferente do que se produzia na outra. A título de exemplo, ao norte do Gâmbia se produzia milheto em grandes quantidades, enquanto ao sul se produzia o arroz, havendo assim trocas comerciais regulares dos dois produtos. ${ }^{32}$

Neste sentido, na Senegâmbia, os agentes que realizavam comércio interno eram de suma importância. Conforme descrito por Philip Curtin, os principais agentes desta atividade eram clérigos muçulmanos, os bixirins ou marabutos (de acordo com as grafias das fontes); os juula, ${ }^{33}$ que comercializavam desde os campos de ouro de Bambuk, até as margens do deserto e da floresta; e os jaxanke, que o autor descreve como soninkés na cultura e na linguagem, muçulmanos na religião, comerciantes e clérigos na ocupação. ${ }^{34}$ Estes agentes atuavam na integração da região, interligando comercialmente áreas distintas, sendo fundamentais em propiciar o que entendemos aqui como "convivência e conveniência” e “complementaridade e transição”, características centrais para se pensar a Senegâmbia como uma zona particular.

Para além desse comércio interno pujante e ativo, com produtos variados que eram levados de uma área a outra por importantes grupos de comerciantes de longa distância, a Senegâmbia não era uma região isolada em um sentido global. No sentido cronológico, a primeira contextualização que devemos fazer é a chegada muçulmana. Séculos antes da

32 Barry, Senegambia and The Altantic Slave trade, pp. 10-25.

33 Curtin elucida que juula era a palavra em malinquê para comerciante, que passou a ser adotada para significar um povo em particular e seu modo de vida, processo que pode ser compreendido através do conceito de etnogênese. Ver: Philip Curtin, Economic Change in Precolonial Africa: Senegambia in the Era of the Slave Trade, Wisconsin: The University of Wisconsin Press, 1975, p. 69.

34 Curtin, Economic Change in Precolonial Africa. 
chegada dos europeus por vias atlânticas, as rotas comerciais transaarianas conectavam a Senegâmbia ao mundo mediterrânico. O Saara permitiu, além do trânsito de mercadorias, o trânsito de ideias e técnicas. ${ }^{35}$

Um dos efeitos deste comércio foi o estabelecimento de muitos árabes e berberes em localidades senegambianas. Estes criavam laços com as populações locais através dos casamentos e se beneficiavam da prática corrente de receber bem o estrangeiro e tratá-lo como hóspede, com a finalidade de construir novas relações comerciais. A presença de árabes na região ajuda a entender a conversão de mandingas e jalofos ao Islã. Estes logo se tornaram agentes islamizadores, uma vez que o comércio foi uma das formas adotadas pelos muçulmanos para a expansão de sua fé. Portanto, as categorias de comércio e conversão não devem ser vistas como instâncias separadas, mas sim como indissociáveis. ${ }^{36}$

A conversão de mandatários políticos, como no caso dos mandingas do Mali e dos jalofos dos vários Estados confederados, favoreceu com que a Senegâmbia fizesse parte do Dar al-Islam, ou seja, do território onde a religião islâmica tem grande número de adeptos. ${ }^{37}$

35 Ghislaine Lydon, em livro de 2009, argumenta que, pelo menos desde 3000 a.C., o Saara nunca foi uma barreira, mas sim uma ponte para trocas intercontinentais. A autora defende que o comércio caravaneiro, na longa duração, envolveu inúmeros grupos que operavam redes de comércio de longa distância e esteve diretamente relacionado à disseminação da alfabetização em árabe e das instituições muçulmanas baseadas na jurisprudência maliki. Em concordância, Idrissa Bah, em recente artigo, demonstrou, inclusive, que mesmo em concomitância com o comércio Atlântico, esta circulação transaariana de mercadorias e de ideias, sobretudo religiosas, dentro da lógica muçulmana, permaneceu acontecendo na longa duração, entre os séculos XI e XX. Para mais, ver: Ghislaine Lydon, On Trans-Saharan Trails: Islamic Law, Trade Networks, and Cross-Cultural Exchange in Nineteenth-Century, Nova York: Cambridge University Press, 2009; Idrissa Ba, "Le commerce transsaharien et ses logiques d'accommodation par rapport au commerce transatlantique entre le XVe et le XIXe siècle”, Varia Historia, v. 36, n. 71 (2020), pp. 329-360.

36 Felipe Malacco, O Gâmbia no Mundo Atlântico: fulas, jalofos e mandingas no comércio global moderno, Curitiba: Brasil Publishing, 2019, p. 47.

37 Este movimento, porém, não foi linear e indisputado. De fato, trata-se de um processo de longa duração e com efeitos para os séculos posteriores. Para mais, ver: Thiago Mota, "História Atlântica da islamização na África Ocidental: Senegâmbia, séculos XVI e XVII”, Tese (Doutorado em História), Universidade Federal de Minas Gerais, Belo Horizonte, 2018. 
Ao fazer parte deste território, por consequência essas regiões conectavam-se também às rotas de comércio que nele existiam. Isso não era interessante apenas aos muçulmanos do deserto do Saara ou do norte da África. Aos mandatários senegambianos também era interessante se conectar a rotas comerciais de longa distância.

Conforme afirma Magalhães Godinho, a principal mercadoria que afluía da Senegâmbia para o norte da África, via Saara, era o ouro e, inclusive, ao chegar ao norte da África, também afluía até a Europa. ${ }^{38}$ Toby Green demonstrou como as cáfilas, além de levar o ouro para o norte da África, também o deslocaram para a costa atlântica nos contatos iniciais com os europeus, relacionando diretamente a extração e o valor mercadológico do ouro ao lugar social ocupado pelos ferreiros na região da Senegâmbia. ${ }^{39}$ Nas fontes, Alvise Cadamosto dá importante testemunho deste fluxo comercial. O viajante veneziano, que foi à Senegâmbia em 1444 em nome da Coroa de Portugal, escreveu:

O ouro que chega de Mali reparte-se em três quinhões: o primeiro vai com a Caravana, que segue o caminho de Mali a um lugar, que se chama Cochia, que fica no caminho que se dirige para Síria e Cairo: a segunda e terceira porção vem em uma Caravana de Mali a Tombuctu, onde se reparte em dois quinhões; hum vai para Toet, e daí se extende para Tunes de Barbaria, e por toda a costa de cima, e o outro vai para Guaden, lugar supranomeado, e daí se espalha por Oran e One, lugares também da Barbaria dentro do Estreito de Gibraltar, e para Fez, Marrocos, Arzilla, Çafim e Messa, lugares de Barbaria fora do Estreito; e neste lugar o compramos nós os Italianos e Cristãos aos Mouros, por diversas mercadorias, que lhes damos: e para tornar ao meu primeiro assunto, esta é a melhor coisa, que se trás da sobredita terra, e país de Azenegues; porque daquela porção de ouro, que chega

38 Vitorino Magalhães Godinho, “O 'mediterrâneo’ saariano e as caravanas do ouro”, Revista de História, v. 11, n. 23 (1955).

39 Green, The rise of trans-Atlantic slave trade in western Africa, 1300-1589, pp. 35-46. 
cada ano a Guaden (como fica dito) trazem alguma às bordas do mar; e esta vendem aos Portugueses, que estão de assento na sobredita Ilha de Arguim para o tráfico da mercancia, em troca de outros gêneros. ${ }^{40}$

Além do ouro, como já foi dito, outro produto importante que afluía da região de Serra Leoa e era levado até o norte da África era a noz de cola. Como descrito por Thiago Mota, "o comércio de noz de cola e sua ligação com Meca foi bastante anterior. George Brooks destacou a importância econômica e política do produto, desde o século XV. Fontes árabes indicam seu comércio desde o século XIII”. ${ }^{41}$ Além de ouro e noz de cola, John Wright salienta que eram exportados da Senegâmbia "peles de animais, marfim, ingredientes para a fabricação de perfumes, e escravizados negros foram transportados pelo deserto de tempos em tempos". ${ }^{42}$

No sentido oposto, do norte da África para a Senegâmbia, o principal produto vendido era o sal. Segundo Djibril Niane, as "minas de Teghazza supriam os mercados do Sudão ocidental; as regiões do rio Senegal obtinham sal-gema em Awlil”, ${ }^{43}$ fato corroborado por John Wright, que afirma que "para o sul, através do deserto, foi o sal saariano essencial para uma dieta sudanesa que de outro modo seria sem sal”. ${ }^{44}$ Richard Jobson, inglês que comercializou no rio Gâmbia em 1621, ao descrever seu trato com o bixirin Buckor Sano, afirmou:

Ele disse que há cerca de seis dias de jornada existe uma cidade chamada Mumbar, onde na próxima lua estes Árabes chegariam: nos

40 Alvise Cadamosto, "Navegações de Luiz de Cadamosto: a que se ajuntou a viagem de Pedro de Cintra, capitão português” in João Muller (org.), Notícias para a história e geografia das nações ultramarinas, (Lisboa: Academia Real de Ciências, [1444] 1812), p. 25.

41 Mota, "História Atlântica da islamização na África Ocidental”, p. 72.

42 John Wright, The Trans-Saharan Slave Trade, Londres: Routledge, 2007, p. 12.

43 Djibril Tamsir Niane, "Relações e intercâmbios entre as várias regiões” in Djibril T. Niane (org.), História geral da África, IV: A África do século XII ao século XVI (Brasília: Unesco, 2010), p. 701.

44 Wright, The Trans-Saharan Slave Trade, p. 33. 
perguntamos de novo quais mercadorias eles trariam, ele respondeu que seria muito sal e diversas outras coisas, nós desejamos saber o que eles queriam em troca: ele disse que nada além de ouro. ${ }^{45}$

Neste excerto, percebemos que mesmo ao longo do século XVII o comércio de sal com o Saara não foi cessado, e temos, novamente, indícios da importância da exportação de ouro saindo da Senegâmbia. Além do sal, John Wright salienta que eram levados no sentido norte-sul no comércio saariano produtos como têxteis, ferro, cobre para cunhagem, armas e armaduras, vidros e contas, equipamentos de equitação e cavalos. ${ }^{46}$

Em 1444 uma nova frente de comércio de longa distância foi aberta para os povos da Senegâmbia. É consenso historiográfico que o advento do comércio atlântico foi fato novo à Senegâmbia e que gerou mudanças significativas sobre como os povos do local faziam comércio de longa distância. Segundo o historiador francês Yves Person "de repente, no século $\mathrm{XV}$, o litoral do Atlântico deixa de ser o fundo de um beco sem saída, utilizado apenas para a pesca costeira e para o comércio local, e passa a constituir uma segunda frente de contato com a Europa”, ${ }^{47}$ Em concordância com este argumento, afirmou Alberto da Costa e Silva: “os portugueses, ao frequentar as costas do Senegal e da Gâmbia, fizeram com que essas áreas deixassem de ser periféricas ou lindeiras dos impérios do Grão Jalofo e do Mali”. ${ }^{48}$

A princípio, a principal mercadoria que motivava os europeus a empreenderem as viagens para a Senegâmbia era o ouro que afluía do Mali. Conforme explicitado por Cadamosto em citação acima, referente a 1444, este conhecimento já dizia respeito, inclusive, ao funcionamento das rotas

45 Richard Jobson, “The Golden Trade: Or, A Discovery of the River Grambra” in David P. Gamble e P. E. H. Hair (org.), The Discovery of River Gambra (1623) by Richard Jobson (Londres: The Hakluyt Society, [1621] 1999), pp. 142-143.

46 Wright, The Trans-Saharan Slave Trade, p. 33.

47 Yves Person, “Os povos da costa: primeiros contatos com os portugueses: de Casamance às lagunas da costa do Marfim” in Niane (org.), História geral da África, IV, p. 339.

48 Alberto da Costa e Silva, A manilha e o libambo: a África e a escravidão, de 1500 a 1700, Rio de Janeiro: Nova Fronteira, 2011, p. 182. 
comerciais pelas quais circulavam o minério. E este afã pelo ouro permanece com o tempo. Richard Jobson, em seu relato de 1621, escreveu:

Ao conversar com qualquer comerciante desta cidade de Londres que tenha anteriormente comerciado na barbária, sendo as partes mais próximas da África, adjacente a nós, e muitas vezes a partir de nosso país em seus principais portos, viajando por 12 dias, e no mesmo tempo retornando, e inquirir a eles onde os Mouros tem rico ouro e eles vão te dizer não há cresce ouro dentro dos limites do Marrocos, enfim o que se sabe ou se faz uso, é que a grande abundância deste rico ouro que eles tem, é buscado e trazido para o país pelos seus habitantes naturais, que fazem grandes viagens que vão somente por terra por onde passam por grandes desertos de areia, que possuem muitos perigos, como é aparente pelas muitas perdas que eles sofrem durante os anos, tanto de pessoas quanto de camelos. ${ }^{49}$

Jobson afirma sobre o conhecimento dos mercadores londrinos da presença de ouro numa região abaixo do deserto do Saara, de onde os marroquinos traziam o produto. O título de seu texto é bem elucidativo quanto ao seu principal interesse em ir ao rio Gâmbia: "O Comércio de Ouro: ou, a Descoberta do rio Gâmbia”. Acreditamos que, de fato, a busca pelo ouro tenha sido um bom impulsionador para os europeus chegarem à África subsaariana. Rapidamente, porém, esse comércio se diversificou em relação aos produtos comprados pelos europeus, como discutiremos adiante.

Embora navegantes a mando da coroa portuguesa tenham sido os primeiros a chegar à Senegâmbia, ao longo do século XVI agentes de outras nações europeias se envolveram ativamente neste comércio, principalmente franceses, ingleses e flamengos. ${ }^{50}$ De fato, enquanto

49 Jobson, "The Golden Trade", p. 78.

50 Philip Havik, Silences and Soundbites: the Gendered Dynamics of Trade and Brokerage in the Pre-colonial Guinea Bissau Region, Leiden: Lit Verlag, 2004, p. 47. 
fatores externos, a União das Coroas espanhola e portuguesa, no período entre 1580 e 1640, fez com que nações europeias, que eram inimigas políticas da Espanha, não se preocupassem em respeitar as tentativas do “monopólio” lusitano na região do rio Gâmbia. ${ }^{51}$

Internamente, como demonstrado pela prática de landlord and strangers reciprocities, não interessava, a princípio, aos comerciantes e mandatários senegambianos a origem dos mercadores estrangeiros, e sim conseguir bons acordos e, no caso dos mandatários, taxações para a realização de comércio. Com relação a essas taxações, André Donelha, que comercializou na Senegâmbia na década de 1580, afirmou que: “detendo-se aqui dois dias [no porto de Jagra no rio Gâmbia para comerciar], deixando alguma pessoa do navio com fazenda para resgatar, pagando ao rei a dádiva que é os direitos ordinários, que é uma peruleira de vinho ou sua valia”. ${ }^{52}$ Em seu relato sobre uma viagem aos rios Senegal e Gâmbia, os ingleses Richard Rainolds e Thomas Dassel fazem uma descrição semelhante: "eu fui para a via de Rufisque: onde eu enviei aos alcaides intérpretes, que vieram abordo, e receberam de mim os impostos do rei para ter tráfico livre com os negros", ${ }^{53}$

Assim, essa confluência de fatores externos e internos levou ao aprofundamentodapresençaeuropeiana Senegâmbia, chegandoaopontode, durante o século XVII, serem criados enclaves comerciais europeus como Cacheu, Gorée, Saint James e Saint Louis. A escolha de “enclave” se deve ao fato de que a palavra premedita a existência de outro Estado com o qual se mantêm relações porosas, de trocas, e, ao mesmo tempo, de dependência. Não se trata, portanto, de um simples depósito de mercadorias, pois envolvia relações políticas, culturais, sociais e econômicas com

51 Walter Rodney, "Portuguese Attempts at Monopoly on the Upper Guinea Coast, 1580-1650”, The Journal of African History, v. 6, n. 3 (1965), pp. 307-322.

52 André Donelha, “Memorial de André Donelha a Francisco Vanconcelos da Cunha” in Brásio, Monumenta, seção II, v. 5, d036, p. 142.

53 Richard Rainolds e Thomas Dassel, "The Voyage of Richard Rainolds and Thomas Dassel to the Riuers of Senega and Gambra Adjoining to Guinea, 1591 with a Discourse of the Treasons of Certaine of Don Antonio his Seruants and Followers”, ש, p. 93. 
as sociedades em seu entorno, mas também não se trata de “colônias”, uma vez que não houve dominação política ou econômica europeia na Senegâmbia antes do século XIX.

Destes contatos entre europeus e senegambianos, um agrupamento de agentes têm sido objeto de destaque nas análises historiográficas: os chamados lançados ou tangomaus. Estes eram agentes, a princípio, de ascendência europeia que se instalavam em terra, ${ }^{54}$ beneficiando-se da prática de landlord and strangers reciprocities, e que, por sua posição junto aos povos locais, tinham vantagens em relação a outros comerciantes externos. Em reação a sua origem e ascendência, Maria João Soares afirma que a "maior parte dos lançados de primeira geração era originária do reino, afluindo depois diretamente aos Rios de Guiné, ou de forma indireta, através da plataforma e 'trampolim' da ilha de Santiago". ${ }^{55}$ De origem social múltipla, eram agentes que são tratados como "mestres da diferença", ${ }^{66}$ executando papel chave de intermediários comerciais, culturais e políticos entre europeus e senegambianos.

Concordamos com a premissa de que estes agentes cumpriam um papel importante no comércio atlântico na Senegâmbia. Porém, é importante salientar que importantes trabalhos historiográficos tratam sobre certa “africanização” dos lançados. Conforme argumentado por Jean Boulègue,

A fusão progressiva dos luso-africanos com os elementos das populações das margens do Gâmbia resultou de diversos fatores. De uma parte, houve a rarefação da imigração de portugueses e cabo-verdianos. De outra parte, a multiplicação de conexões familiares

54 Isso porque, com o tempo, surgem filhos de lançados com mulheres locais, que mantém os traços culturais distintivos que caracterizam estes agentes.

55 Soares, "Para uma compreensão dos lançados nos Rios da Guiné”, p. 173.

56 Termo utilizado por Toby Green para a presença dos judeus e cristãos novos em Cabo Verde e na Senegâmbia, neste segundo espaço na condição de lançados. Para mais, ver: Toby Green, Master of Difference: Creolization and the Jewish Presence in Cabo Verde, 1497-1672, Birmingham: University of Birmingham, 2007. 
com as populações locais tendeu a africanização mais e mais completa da comunidade que ficava menos numerosa. ${ }^{57}$

Alberto da Costa e Silva defende também que é a conformação de famílias com mulheres locais que auxiliou nesse processo de africanização. Segundo o autor, as mulheres dos lançados eram peça chave para que os lançados se conectassem às redes políticas e comerciais na Senegâmbia, e também por meio delas "familiarizarem-se com os costumes da terra e passaram a viver sem ofendê-los". ${ }^{58}$ Além disso, ao se instalarem na Senegâmbia, onde não havia colonização europeia, sem nenhum poder de mando, os lançados passaram a ser mobilizados pelos mandatários locais e atuarem a seu favor. Segundo Boulègue:

O papel dos intermediários [exercido pelos lançados] não deve ser entendido como um papel neutro. Eles operavam em contato com parceiros de negócios europeus e africanos, mas é nas sociedades africanas que foram implantados. As cidades onde viviam, as rotas que eles frequentavam, estavam sob o controle dos reis senegambianos. Então, eles foram os agentes econômicos dos mesmos. ${ }^{59}$

Em conjunto com os agentes internos, os lançados, então, faziam o papel de comercializar com mercadores vindos do Atlântico, a favor das próprias soberanias locais. Uma das principais características deste comércio é a diversidade de mercadorias que nele circulavam. Com relação aos produtos comprados pelos comerciantes atlânticos, o relato dos ingleses Richard Rainolds e Thomas Dassel é bem explicito em relação a essa variedade ao descrever as mercadorias que compraram entre o rio Senegal e o rio Gâmbia:

57 Jean Boulègue, Les Luso-Africains de Sénégambie, XVIe - XIXe siècles, Lisboa: Instituto de Investigação Científica Tropical; Paris: U. de Paris, 1989, p. 78.

58 Silva, A manilha e o libambo, p. 239.

59 Boulègue, Les Luso-Africains de Sénégambie, p. 89. 
Os principais lugares de tráfico naquela costa entre esses rios são: 1 Rio Senegal: As mercadorias são peles, goma, dentes de elefantes, alguns grãos, penas de avestruz, âmbar cinzento e ouro. 2 Bezeguiche, uma cidade de Cabo Verde há poucas léguas do rio Senegal: as mercadorias são pequenas peles e alguns dentes. 3 Rufisque, uma cidade a 4 léguas de Bezeguiche: As mercadorias são pequenas peles e alguns dentes de vez em quando. 4 Palmerin, uma cidade a 2 léguas de Rufisque: As mercadorias são pequenas peles e alguns dentes de elefantes de vez em quando. 5 Porto D’Ale, uma cidade a 5 léguas de Palmerin: As mercadorias são pequenas peles, dentes, âmbar e um pouco de ouro: e muitos portugueses estão lá. 6 Candimal, uma vila a um quarto de légua do Porto D’Ale: as mercadorias são pequenas peles e alguns dentes de vez em quando. 7 Palmerin, uma cidade há 3 léguas de Candimal: as mercadorias são pequenas peles e alguns dentes de vez em quando. 8 Joola, uma cidade a 6 léguas de Palmerin: as mercadorias são peles, cera, dentes de elefantes, arroz e ouro: e muitos espanhóis e portugueses estão lá. 9 Rio Gâmbia: As mercadorias são arroz, cera, peles, dentes de elefantes e ouro. ${ }^{60}$

Percebemos, por este excerto, a possibilidade de se comercializar, em uma parte significativa da Senegâmbia, pelo menos oito mercadorias diferentes. Dessa forma, a primeira premissa que um estudo sobre comércio na Senegâmbia nos séculos XVI e XVII deve procurar entender é esta diversidade. Partindo desta premissa, conseguimos perceber que três mercadorias são mais recorrentes nas fontes, por causa do volume e importância de sua exportação: o couro, o marfim e as pessoas escravizadas.

O couro era muito procurado pelo intensivo uso que possuía no início da Era Moderna, antes da invenção de materiais sintéticos como o plástico. ${ }^{61}$

60 Rainolds e Dassel, “The Voyage of Richard Rainolds and Thomas Dassel”, pp. 90-91.

61 Para mais, ver: L. A. Clarkson, “The Organization of the English Leather Industry in the Late Sixteenth and Seventeenth Centuries”, The Economic History Review, v. 13, n. 2 (1960), p. 245-256. 
Essa demanda europeia encontrou significativa oferta por parte dos povos senegambianos. Segundo Claude Jannequin, mercador francês que foi ao rio Senegal em 1643, "nós tratamos todas as mercadorias que encontramos, como couros de bois, cervos, leões e leopardos”. ${ }^{62}$ Francisco Lemos Coelho, por sua vez, afirmou que no forte de Saint James no rio Gâmbia a principal mercadoria comprada pelos ingleses era "couros de vaca, e de bicho, e é melhor a de bicho que consta de antas, sinsins, tancois, gimguicamgas”. ${ }^{63}$

É importante salientar que o comércio de couro mobilizava tanto a produção interna na Senegâmbia quanto rotas de comércio de longa distância internas ao continente. Segundo Michel de La Courbe, comerciante francês que comercializou na Senegâmbia e produziu um relato em 1685, "todos estes mouros vão recolher a goma e trazê-la mais de cem léguas sobre camelos, e grandes bois carregando como cavalos; eles também matam tigres, onças e avestruzes, cujas peles e penas vendem”, ${ }^{64}$ Conforme se percebe, os caravaneiros sahelianos também se envolviam no comércio desta mercadoria.

Na Senegâmbia entre 1580 e 1700, povos nômades pastoris como os fula se destacavam no comércio desta mercadoria. Porém, conforme explicitado por Boulègue, a principal mercadoria da região, considerando todos os povos, eram "os couros bovinos [...] sob o qual a procura era tal que o couro pode ser considerado como o principal comércio da economia dos reinos Jalofos (e senegambianos em geral)”. ${ }^{65}$

O marfim, por sua vez, é um produto que aparece como possibilidade de comércio por vias atlânticas em, literalmente, toda a costa e margem dos rios senegambianos. Com grande procura por parte dos

62 Claude Jannequin, Voyage de Libye au royaume de Senegal, le long du Niger: avec la description des habitants qui sont le lon de ce fleuve, leurs coûtumes et façons de vivre, les particularités les plus remarquables de ces pays, Paris: Gallica, 1643, pp. 66-67.

63 Coelho, Duas descrições seiscentistas de Guiné, p. 13.

64 Michel La Courbe, Le premier voyage du sieur de La Courbe Fait à la Coste d'Afrique en 1685, Paris: Société d’Histoire des Colonies Françaises, 1913, p. 147.

65 Jean Boulègue, Les royaumes wolof dans l'espace sénégambien (XIIIe-XVIIIe siècle), Paris: Karthala, 2013, p. 199. 
europeus, o marfim constituía uma das poucas mercadorias de origem orgânica cujo valor rivalizava com materiais como gemas e metais nobres. ${ }^{66}$

Vendido principalmente em estado bruto, as descrições mais minuciosas sobre o comércio do marfim são daqueles povos que os comerciantes conseguiam escrever sobre o processo de caça aos elefantes, como os mandingas ${ }^{67}$ e os jalofos. ${ }^{68}$ Porém, assim como o couro, o comércio de marfim não mobilizava apenas os povos costeiros. Conforme escrito por Francisco Lemos Coelho "vem outra casta de negros [para Baracunda, no Gâmbia] a que chamam conjuros, que vem buscar o mesmo que os Jaganzes; vem logo muitas cáfilas de negros a que chamam Bachares, estas são de oitenta, cem homens, não trazem outra coisa mais que marfim”. ${ }^{6}$

O comércio de pessoas também foi importante na Senegâmbia entre 1580 e 1700 . De acordo com dados disponíveis na base de dados Slave Voyages, entre 1580 e 1700144.203 pessoas foram colocadas na condição de escravizados e comercializadas a partir dos portos da Senegâmbia. ${ }^{70}$ Estes números nos dão um indicativo do volume de venda de escravizados, mesmo com os limites que informam os registros e estimativas dessa base de dados.

Internamente, os processos de escravização se davam principalmente a partir de guerras e de um aparato jurídico cujas penas, atendendo à inesgotável demanda atlântica, foram se tornando cada vez mais relacionadas à

66 Luís Afonso e José da Silva Horta, “Olifantes afro-portugueses com cenas de caça c.1490-c.1540”, Artis, n. 1 (2013), p. 28.

67 Ver: André Álvares Almada, “Tratado breve dos rios de Guiné do Cabo Verde dês do Rio Sanagá até os Baixos de Santa Ana” in Brásio, Monumenta, seção II, v. 3, d092, p. 305; e Jobson, “The Golden Trade”, p. 174.

68 Ver: Jannequin, Voyage de Libye au royaume de Senegal, pp. 144-145.

69 Coelho, Duas descrições seiscentistas de Guiné, p. 24. Para estudos recentes sobre o comércio de marfim na Senegâmbia e outras partes do Mundo Atlântico, ver: Vanicléia Silva Santos (org.), O marfim no mundo moderno: comércio, circulação, fé e status social (séculos XV-XIX), Curitiba: Prismas, 2017; Vanicléia Silva Santos, Eduardo França Paiva e René Lommez Gomes (orgs.), O comércio de marfim no mundo atlântico: circulação e produção (séculos XV a XIX), Belo Horizonte: Clio Gestão Cultural e Editora, 2018.

70 A base de dados online Slave Voyages, $\smile$, cujos pesquisadores principais são David Eltis e Martin Halbert, reúne informações de mais de 35 mil viagens de navios negreiros. 
escravização dos réus, ${ }^{71}$ Assim como o couro e o marfim, também havia possibilidade de as pessoas escravizadas serem trazidas pelas rotas comerciais de longa distância. Conforme escrito por Michel de La Courbe, "no rio Gâmbia nós negociamos uma quantidade de cativos, que são vendidos a você pela realeza do país, ou por algum indivíduo privado, ou por comerciantes Mandinga, que os trazem por mais de 300 léguas”. ${ }^{72}$

Quanto aos produtos mais comprados pelos agentes senegambianos, destacamos o sal e o ferro. Como dissemos, o sal foi um produto de primeira necessidade na era Moderna. Importante na conservação e preparo de alimentos, era uma mercadoria intensamente procurada pelos senegambianos. Percebe-se também que não era um produto novo. Na verdade, os europeus levavam para comercializar na Senegâmbia um produto que já afluía nas rotas saarianas, o que nos permite concluir que o comércio atlântico euro-senegambiano não criou uma nova lógica de comércio, mas sim ampliou lógicas preexistentes.

Além disso, temos indícios também de que os europeus nem sempre traziam o sal direto da Europa. Em Lemos Coelho, conseguimos perceber como ele comprou sal que era produzido nas salinas das ilhas de Telam, próximas a foz do rio Gâmbia, para comercializar rio acima: “dentro deste rio estão as ilhas de Telam, que são duas, em as quais se faz sal em muita quantidade [...]. Eu mandei o meu navio três vezes, nos três anos que nela assisti, a carregar, com o que fiz bom negócio”. ${ }^{73}$

O mesmo se passa com o ferro. A relevância da mercadoria era tal que Jean Boulègue associa o fato dos europeus passarem a levar ferro para trocar na Senegâmbia à diversificação das mercadorias que conseguiam obter. $^{74}$ John Thornton argumenta que embora já fosse um produto existente na lógica comercial senegambiana, produzido

71 Paul Lovejoy, A Escravidão na África: uma história de suas transformações, Rio de Janeiro: Civilização Brasileira, 2002, pp. 141-146.

72 La Courbe, Le premier voyage du sieur de La Courbe, pp. 193-194.

73 Coelho, Duas descrições seiscentistas de Guiné, p. 110.

74 Jean Boulegue, Les royaumes wolof, p. 211. 
sobretudo no Futa Jalon, a demanda por ferro por parte dos povos costeiros na Senegâmbia era grande. ${ }^{75}$ Assim, acabou por se tornar uma das principais mercadorias vendidas pelos europeus. Sua importância é tal que o mercador flamengo Pieter Van den Broecke, em 1606, utiliza barras de ferro como medida de valor para as mercadorias que comprou na costa entre o rio Senegal e o rio Gâmbia, nomeadamente marfim, âmbar, cera, arroz e couro. ${ }^{76}$

A significativa demanda por ferro advém pelos desdobramentos políticos da abertura da nova via comercial atlântica. Os maiores centros políticos, no sentido da abrangência e poder de mando na Senegâmbia, como o Mali e o Gran-Jalofo, eram localizados em regiões interioranas, próximas aos entrepostos comerciais saarianos. Com a intensificação do comércio atlântico, centros próximos às costas e margens dos rios passam a ter cada vez mais poder econômico e, a partir disso, configurou-se um aumento de poder político e militar. Assim, unidades políticas como o Kaajor e o Saalum jalofo, o Kaabu e o Casamansa dos mandingas, começaram a ter um maior controle político da região, sem depender de poderes interioranos. E, neste processo, o ferro foi um produto de grande importância para confecção de aparato bélico, conforme fica explícito no relato de André Almada, produzido em 1594, em que afirma que o ferro era fundido por ferreiros locais às margens do rio Gâmbia e transformados em azagaias, dardos, facas e flechas. ${ }^{77}$

Como se percebe, o comércio atlântico, ao menos no sentido das mercadorias que eram trocadas na Senegâmbia, não causou profundas alterações no comércio interno. Inclusive, de acordo com as fontes, conseguimos perceber que as rotas atlânticas não interromperam o comércio interno na Senegâmbia e nem mesmo transformaram completamente as

75 John Thornton, A África e os africanos na formação do mundo Atlântico, 1400-1800, Rio de Janeiro: Elsevier, 2004, pp. 90-91.

76 Pieter Van Den Broecke, “Journal of Voyages to Cape Verde, Guinea and Angola” in James La Fleur (org.), Pieter Van Den Broeckes: Journal of Voyages to Cape Verde, Guine and Angola (1605 - 1625) (London: The Hakluyt Society, [1606] 2000).

77 Almada, “Tratado breve dos rios de Guiné do Cabo Verde”, p. 273. 
suas dinâmicas preexistentes. ${ }^{78}$ Francisco Lemos Coelho, novamente, traz exemplos elucidativos deste argumento:

Em este porto de Baracunda [no rio Gâmbia] [...] vem as cáfilas dos negros mercadores, dos quais a mais grandiosa há a de uma casta de negros que chamam Jagancases [jaxanke] em a qual vem mais de três mil pessoas e mais duas mil bestas asnares [...] Dizem que destas partes partem no mesmo tempo três cáfilas, e que vem uma para este rio, outra vai para o rio de Sanagá e outra que vai para o rio Deponga, e todas o principal negócio que vem buscar é sal, e os que vem a este rio não compram ao branco mas passam até a boca do rio, as ilhas de Telam, aonde compram a troco de roupa. Aos donos dos navios, vendem muitos negros, marfim e ouro, que esta cáfila é a que trás a maior quantidade deste gênero, e entendo trazem o melhor de uma arroba de ouro, que a gente da terra também lhe compra melhor que o branco, que não faz muito por ele, porque em qualquer outro gênero que empregue seu dinheiro lhe tem mais conta. ${ }^{79}$

Nos grifos, percebemos duas importantes características da cáfila dos jaxankes. A primeira é que não compram sal dos europeus, e sim nas próprias ilhas de Telam, no rio Gâmbia; além disso, vendem ouro a melhor preço para os povos locais do que para os europeus, que, tendo sua margem de lucro reduzida, preferem comprar outras mercadorias. Tratamos esta informação, que encontra eco em outras fontes como os relatos Richard Jobson e Michel de la Courbe, como indício da permanência de redes de comércio internas à Senegâmbia.

Porém, com o advento e intensificação do comércio atlântico, houve, de fato, reorientação e criação de novas rotas. Neste sentido,

78 Conforme demonstrado por Idrissa Ba, por exemplo, o comércio saariano, longe de desaparecer após o advento do comércio atlântico, na realidade experimentou um ressurgimento das suas atividades, com variações nos seus produtos em circulação e também com variações regionais. Ver: Idrissa Ba, “Le commerce transsaharien”, p. 342.

79 Coelho, Duas descrições seiscentistas de Guiné, p. 131 (grifo nosso). 
o comércio da goma arábica é elucidativo. Comercializada, sobretudo, entre franceses, fulas e jalofos no rio Senegal na segunda metade do século XVII, o produto era coletado em árvores acácia na região do Sahel por agentes que se conectavam com o comércio saariano e levado até os portos atlânticos e margens do Senegal.

Segundo Michel de la Courbe, ao perguntar ao Brak, mandatário da unidade política jalofa do Wallo, porque ele, em específico, não comercializava a goma arábica, a resposta foi a seguinte: "perguntei-lhe porque os negros não estavam tirando proveito desta goma-arábica, já que tendo em seu país, eles não vão coletá-la. Ele me disse, por toda razão, que seus pais e avós nunca haviam feito esse comércio”, se limitando a cobrar impostos pela realização do comércio em suas terras ${ }^{80}$ Porém, ainda assim, o mercador francês comercializou goma suficiente subindo o rio Senegal, ao ponto de "não ter barcos o suficiente para removê-la prontamente". ${ }^{81}$

Este exemplo é elucidativo. Nos mostra alguns dos fatores que buscamos demonstrar neste tópico: eram agentes internos que traziam a goma arábica do interior; os mandatários locais se beneficiavam diretamente do comércio, mesmo quando não era diretamente sob seu mando que as trocas comerciais se realizavam; e os portos atlânticos e as redes saarianas eram conectadas comercialmente pelos agentes que faziam o comércio interno na Senegâmbia. Somando-se aos fatos de que o comércio atlântico não acabou com o comércio interno e nem modificou essencialmente as mercadorias que circulavam na Senegâmbia, conseguimos compreender a autonomia local na realização das trocas mercantis e entender a macrorregião como parte constitutiva e não mera espectadora do comércio durante a Era Moderna.

80 La Courbe, Le premier voyage du sieur de La Courbe, p. 167.

81 La Courbe, Le premier voyage du sieur de La Courbe, p. 165. 


\section{Nas rotas dos mambari: autoridades e negociantes no comércio de longa distância a partir do Planalto Central Angolano}

Em 29 de março de 1854, em viagem saída do Barotse, no oeste da atual Zâmbia, com destino à ilha de Moçambique, na costa oriental da África, a caravana de oficiais subordinados a Silva Porto - os chamados pombeiros $-{ }^{82}$ passou pela terra de um mandatário local, um soba, de nome Cutumbuca. ${ }^{83}$ No relato dos pombeiros de Silva Porto, o qual foi incluído em seus cadernos, há uma passagem interessante em que o soba Cutumbuca, ao saber da existência de um boato de que iria sequestrar a caravana, respondeu que:

os seus desejos [do soba Cutumbuca] limitavam a ter continuamente viajantes na sua terra, estranhando o mal intencionado que havia feito circular rumores [de que o soba ia sequestrar a caravana] - cujo sentido, tinha em mira afugentá-los [a caravana], o que nunca lhe tinha passado pela ideia; visto que os sobas não podiam prescindir dos viajantes. ${ }^{84}$

82 Segundo Beatrix Heintze, a denominação pombeiro tem uma longa história, sendo que esse termo derivaria de mpundu, relacionado ao grande mercado junto ao lago Malebo e, posteriormente, a todos os mercados mais importantes no Congo. Como afirma Mariana Candido, a princípio o termo era usado para se referir aos homens portugueses, mas depois seu uso foi sendo generalizado para descrever os comerciantes negros e mulatos, sendo por muito tempo sinônimo de negociante africano de escravos dos portugueses em Angola, sendo quase sempre um escravo de confiança. Na segunda metade do XIX, eram majoritariamente indivíduos livres que serviam de intermediários nas grandes caravanas. Ver: Beatrix Heintze, Pioneiros africanos: caravanas de carregadores na África Centro-Ocidental (entre 1850 e 1890), Lisboa: Caminho, 2004, pp. 274-275; Mariana Pinho Candido, Fronteras de esclavización: esclavitud, comercio e identidad en Benguela, 1780-1850, Cidade do México: El Colegio de México, 2011, p. 44.

83 Originalmente o termo soba vem do kimbundu e era utilizado para os mandatários locais subordinados ao rei do Ndongo, antigo estado localizado na região do rio Kwanza. No entanto, é frequente que as fontes portuguesas em Angola se refiram a mandatários africanos em geral como sobas, mesmo em regiões não falantes do kimbundu, como é o caso dessa autoridade, cujo domínio se localizava em algum ponto que atualmente estaria entre o oeste da Zâmbia e o norte de Moçambique.

84 Sociedade de Geografia de Lisboa (SGL), Lisboa, res. 2 - C - 6; António Francisco Ferreira da Silva Porto, Viagens e apontamentos de um portuense em África, v. 1, fl. 375, 29 mar. 1854. 
Falas como a desse mandatário, valorizando a passagem de viajantes por suas terras por causa do fornecimento das riquezas que circulavam no comércio de longa distância, são recorrentes nos diários de Silva Porto. Com a clara intenção de incentivar mais visitas de comerciantes por suas terras, a fala desse soba mostra o quanto os séculos de comércio de longa distância na África Central, com a entrada pelo Atlântico de diversas mercadorias para a troca por escravizados, sendo elas de origem europeia, asiática ou americana (a exemplo de tecidos manufaturados, bebidas alcóolicas ou armas de fogo), consolidaram demandas de mandatários e seus súditos por produtos importados - mesmo em regiões tão distantes do litoral. ${ }^{85}$

Localizado a sul do rio Kwanza, o Planalto Central foi uma das principais regiões de proveniência dos escravizados embarcados na África Centro-Ocidental para as Américas. Sendo uma região sempre marcada por grande densidade populacional, e com várias ligações com diferentes rotas comerciais de longa distância para o interior, o Planalto forneceu, desde meados do século XVI, cativos para o comércio de Luanda e, após o XVII, também para Benguela. ${ }^{86}$ Muitos historiadores dessa região pressupõem que existe uma unidade identitária entre os povos do Planalto, utilizando o termo ovimbundu, etnônimo aplicado a partir do período colonial, em seus estudos para os séculos anteriores. ${ }^{87}$ No entanto, Mariana Candido

85 Sobre as redes oceânicas que alimentavam as demandas do comércio interno de escravizados em Angola, ver: Roquinaldo Ferreira, "Dinâmica do comércio intracolonial: geribitas, panos asiáticos e guerra no tráfico angolano de escravos (século XVIII)” in João Fragoso, Maria Fernanda Bicalho e Maria de Fátima Gouvêa (orgs.), O Antigo Regime nos trópicos: a dinâmica imperial portuguesa, séculos XVI-XVIII (Rio de Janeiro: Civilização Brasileira, 2001), pp. 339-378.

86 Joseph C. Miller, “Angola central e sul por volta de 1840”, Estudos Afro-Asiáticos, n. 32 (1997), pp. 19-20.

87 O termo ovimbundu é o plural de ocimbundu, que durante o período colonial foi traduzido do umbundu como "negros". Tal definição foi elaborada no contexto de crescente racialização com a aplicação das primeiras leis que regularam o trabalho e cidadania daqueles que passaram a ser classificados como “indígenas” no final do século XIX e início do XX. Ver por exemplo: José Pereira do Nascimento, Grammatica do Umbundu ou Língua de Benguella, Lisboa: Imprensa Nacional, 1894, p. 14. Para exemplos de historiadores que usam o termo na longa duração, ver: Linda M. Heywood, Contested power in Angola: 1840s to the present, Rochester: University of Rochester Press, 2009; Éva Sebestyén, “A sociedade ovimbundu nos relatórios de viagens do húngaro László 
critica o uso indiscriminado desse etnônimo para períodos anteriores ao século XX, observando que os povos do Planalto, quando deixaram seus traços nas mais diversas documentações, identificavam-se de acordo com a autoridade política de que eram súditos, dizendo serem, por exemplo, provenientes do Bié, Bailundo, Huambo ou de Caconda, e, portanto, não se afirmando como ovimbundu. ${ }^{88}$

A violência generalizada a partir dos séculos XVI e XVII por causa das razias escravizadoras que passaram a ser realizadas contra as populações do Planalto levaram vários habitantes da região a procurar proteção oferecida por parte de chefes guerreiros (em inglês warlords), provavelmente provenientes de outras regiões, que mantinham fortalezas e reuniam contingentes militares responsáveis por parte dessas razias. Essa mudança no cenário político da região se consolidaria no século XVIII, em que, com a chegada de maior quantidade de armas de fogo, não só esses mandatários forneceriam contingentes cada vez maiores de cativos para o litoral, como centralizariam o poder nas mãos de alguns Estados africanos fortes e autônomos frente à frágil estrutura administrativa portuguesa da região, a exemplo do Huambo, do Bailundo e do Bié. ${ }^{99}$

Magyar: sul de Angola, meados do século XIX”, História: Debates e Tendências, v. 15, n. 1 (2015), pp. 83-100. Há, por outro lado, historiadores que defendem existir uma identidade comum aos povos do Planalto ligada à grande homogeneidade das estruturas políticas, sociais e culturais dos povos falantes de umbundu, que estariam ligados a uma origem comum desses Estados. Assim, no lugar de ter o sentido racializado das ditas traduções europeias, tal termo serviria de distinção utilizada principalmente frente aos povos a leste do planalto, que chamavam de ngangela. Portanto, para esses autores haveria uma unidade cultural no Planalto, mas não necessariamente os povos se identificavam como ovimbundu. Ver mais em: Ceita, "Silva Porto na África Central - Viye / Angola”, pp. 121-125; Miller, “Angola central e sul por volta de 1840”, p. 17.

88 Como mostra a autora, a mesma consideração vale para a autoidentificação desses sujeitos na diáspora. Ver: Mariana Candido, An African Slaving Port and the Atlantic World: Benguela and its Hinterland, Nova York: Cambridge University Press, 2013, pp. 292-293. Conclusão análoga pode ser tirada dos dados reunidos por Daniel Domingues da Silva, The Atlantic Slave Trade from West Central Africa 1780-1867, Nova York: Cambridge University Press, 2017, p. 108.

89 Miller, “Angola central e sul por volta de 1840”, pp. 14-17; e Way of Death: Merchant Capitalism and the Angolan Slave Trade, 1740-1830, Madison: University of Wisconsin Press, 1988, pp. 140-141. 
Rotas do Comércio Longa Distância da África Centro-Ocidental ${ }^{90}$

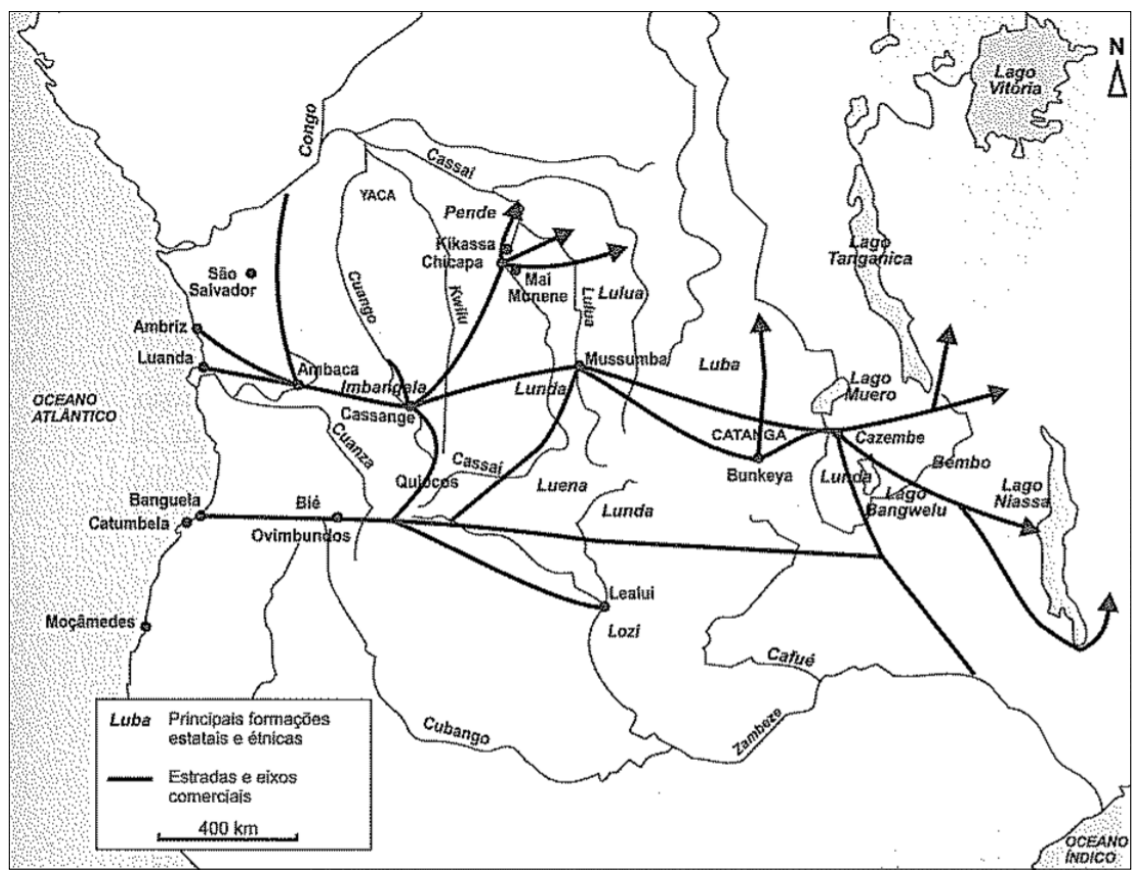

A busca crescente por escravizados pelos povos do Planalto não só levaram a muitos desses chefes guerreiros realizarem razias contra os povos a leste da região, como levaram a comerciantes buscarem comprar escravizados em regiões cada vez mais distantes, tendo contato na segunda metade do século XVIII com povos do Alto Zambeze e do rio Kasai, décadas antes da passagem de qualquer negociante de origem europeia por essas regiões. No interior, esses comerciantes do Planalto eram chamados de mambari e foram agentes fundamentais de conexão desse interior profundo, a centenas de quilômetros do litoral, com o Atlântico e,

90 Elikia M’Bokolo, África Negra: história e civilizações, Salvador: Edufba, 2011, t. 2, p. 235. 
consequentemente, foram os principais fornecedores para tais povos de produtos importados vindos do Oceano. ${ }^{91}$

Esses contatos diretos realizados com comerciantes vindos do litoral, ou indireto, com o intermédio de negociantes africanos como os mambari, ajudaram a integrar ao longo dos séculos as diversas regiões que formaram a zona atlântica. A zona atlântica compreendia uma malha de diversos territórios do interior, em constante expansão, que se conectavam às redes de longa distância, circulando não só mercadorias, mas também pessoas (livres e escravizadas), ideias e culturas, consistindo em uma área de irradiação da economia angolana. ${ }^{92}$ Uma demonstração do poder e da longa extensão dessa zona é que, quando os primeiros comerciantes portugueses chegaram no Luvale, no Alto Zambeze, que até então tinha tido somente contato indireto com a zona atlântica, a demanda comercial por produtos importados dos povos dessa região era extremamente específica: cinco tipos de tecidos e dois tipos de missangas. ${ }^{93}$

As formas de contato direto ou indireto com tais rotas de longa distância muitas vezes estavam ligadas a decisões políticas das elites reinantes. Um exemplo claro é o do Barotse. Segundo tradições orais,

91 Achim Von Oppen, Terms of Trade and Terms of Trust: The history and Contexts of Pre-Colonial Market Production around the Upper Zambezi and Kasai, Münster: Lit Verlag, 1994, pp. 53-54. O termo mambari seria derivado da palavra quimbares, que Silva Porto define como os escravizados dos brancos. No entanto, em passagem posterior, Silva Porto comenta que, no interior, chamam de quimbares os bianos em geral, além de todos os negociantes que passavam pela região. SGL, res. $2-\mathrm{C}-6$, fl. 28-29, António Francisco Ferreira da Silva Porto, Viagens e apontamentos de um portuense em África, v. 2, 4 jan. 1861; Biblioteca Pública Municipal do Porto (BPMP), Porto, ms. 1238, fl. 83. António Francisco Ferreira da Silva Porto, Viagens e apontamentos de um portuense em África, v. 3-BIS, 7 dez. 1863.

92 Utilizamos aqui o conceito de "zona atlântica” no sentido atribuído por Achim Von Oppen, Terms of Trade and Terms of Trust, pp. 49, 53-54. Para um sentido mais circunscrito de "zona atlântica", ver: Miller, Way of Death, p. 141. Ver também a noção de Vellut de "fronteira luso-africana", em que Oppen afirma se inspirar na sua noção de zona atlântica: Vellut, "Notes sur le Lunda et la frontière luso-africaine (1700-1900)”, pp. 140-145.

93 Esse dado é proveniente do relato da viagem de Alexandre da Silva Teixeira que, a partir de 1794, partiu da feira de Kasanje com destino a Tete, no atual Moçambique. Ver: Oppen, Terms of Trade and Terms of Trust, p. 59. 
no início do século XIX, teria chegado às planícies inundadas do povo lozi, no que hoje corresponde ao oeste da Zâmbia, uma caravana de mambari oferecendo bens importados em troca de escravizados. O soberano lozi, Mulambwa Santulu, teria recusado o acordo, afirmando que "amava demais o seu povo para pensar em vendê-lo”, se recusando a se integrar diretamente ao comércio da zona atlântica. ${ }^{94}$ Para além de ser um suposto amante de seu povo, o historiador Jack Hogan justifica a decisão de Santulu pela centralidade e demanda intensa que o Estado lozi tinha na época por escravizados, evitando o comércio com os mambari para assim não perder contingentes tão necessários. Essa dependência era tão grande que, mesmo já havendo uma valorização dos produtos importados do Atlântico vindos indiretamente pelo comércio do Norte, com o Luvale e a Lunda, o soberano lozi preferiu manter o contato indireto para não ter que gastar escravizados nas trocas. ${ }^{95}$

Esse relativo isolamento do Barotse com a zona atlântica foi interrompido por volta da década de 1840, quando os kololo, povo da África Austral de origem sotho, tomou o poder da Planície. Após a morte de Santulu e uma série de conflitos sucessórios, os kololo, que já ocupavam a porção sul do território, tomaram o controle da Planície e abriram o comércio do reino para as caravanas mambari. Interessados principalmente nas armas de fogo trazidas pelos negociantes do oeste, os novos soberanos da terra inclusive mudaram a capital do país para Linyanti, local central para a reunião das presas de marfim coletadas pelos caçadores do país, que, como explicaremos na sequência, era o principal produto demandado pelos mambari nessa época. ${ }^{96}$ Oppen levantou inclusive a hipótese de que o desejo dos soberanos kololo pelo contato direto com as rotas atlânticas

94 Jack Hogan, “The Ends of Slavery in Barotseland, Western Zambia (c. 1800-1925)”, Tese (Doutorado), University of Kent, Canterbury, 2014, pp. 67, 71-73.

95 Com a Lunda os lozi permutavam gado bovino por tecidos, e com o Luvale recebiam principalmente tecidos, louça e contaria. Não há registros de quais produtos os lozi trocavam com os luvale, mas Hogan aponta que havia uma série de gêneros produzidos na planície do Barotse que eram demandados nas áreas mais altas, incluindo os reinos a Norte. Hogan, “The ends of slavery” pp. 67, 74-75.

96 Hogan, “The Ends of Slavery in Barotseland”, pp. 75-78. 
era tão alto que teria sido o acesso às mercadorias importadas do atlântico via Luvale uma das principais motivações de terem procurado expandir seu domínio ao Norte. ${ }^{97}$

Para além do campo de decisões dos mandatários africanos, é importante destacar a atuação dos agentes que a historiografia geralmente cunhou de "luso-africanos” para a fabricação e manutenção de conexões comerciais oceânicas e continentais. Atuando por extensas redes informais que obedeciam mais a ligações de parentesco e compadrio do que a regulações mercantilistas do "império ultramarino", a malha dos agentes luso-africanos era demasiadamente diversa sobre as suas origens culturais e sociais, incluindo desde as grandes famílias da elite luandense, formadas geralmente pela união de mulheres locais com homens estrangeiros, até os homens de distintos carizes raciais que moravam no interior dos sobados os sertanejos. ${ }^{98}$ É frequente inclusive que historiadores definam também como parte da comunidade luso-africana comerciantes africanos que se utilizavam de alguns poucos elementos culturais portugueses, como vestuário ou a língua, para ter vantagens comerciais no litoral. ${ }^{99}$ Entendemos que, mesmo havendo uma situação análoga de atuação desses diversos agentes entre vários universos culturais ligados à presença portuguesa na região, é mais interessante utilizarmos os termos de época, como sertanejos, pombeiros ou quissongos, que revelam mais sobre a origem e atuação desses sujeitos no comércio do interior, do que entendê-los em função de grandes classificações como luso-africano, euro-africano ou lusófonos.

Como já dito, o Planalto Central desde meados do XVI foi conectado nas redes do comércio de escravizados para Luanda, seguindo

97 Oppen, Terms of Trade and Terms of Trust, p. 72.

98 Thompson, “O Atlântico Sul”, pp. 97-98; Mariana Candido, “Os agentes não-europeus na comunidade mercantil de Benguela, c. 1760-1820”, Saeculum - Revista de História, v. 29, (2013), p. 98. Para mais sobre a importância dessas uniões matrimoniais para o exercício do comércio nas cidades da costa angolana, e sobre a posição de protagonismo dessas mulheres luso-africanas nessas atividades, ver: Vanessa dos Santos Oliveira, "The Gendered Dimension of Trade: Female Traders in Nineteenth Century Luanda”, Portuguese Studies Review, v. 23, n. 2 (2015), p. 93-121.

99 É o caso de Mariana Candido, Fronteras de esclavización, pp. 43-45. 
as rotas pelas margens do rio Kwanza, onde os portugueses instalaram uma série de fortalezas, os presídios, ao longo dos séculos. Por essa razão, nas décadas de 1810 e 1820, muitos sertanejos provenientes dos presídios dessa região, como Pungo Andongo, Cambambe e Massangano, se instalaram na corte do reino do Bié para formarem caravanas para levar escravizados para Luanda. Sendo o mercado mais povoado por sertanejos no Planalto, contando com cerca de 200 moradores nessa época, muitos deles provenientes de Benguela e Luanda, para além dos presídios e, por vezes, até mesmo naturais de Portugal e do Brasil, o Bié recebeu os primeiros sertanejos na década de 1770. Encontrando condições comerciais melhores do que no presídio português de Caconda, esses sujeitos aproveitavam a grande disponibilidade de escravizados na região e a distância que dificultava os esforços de fiscalização comercial da administração portuguesa. ${ }^{100}$

O preço que esses agentes pagavam por fugir das autoridades portuguesas era o de obedecer às autoridades africanas autônomas. Os sertanejos não só tinham que manter-se aliados dos grandes mandatários da região, em especial o soba do Bié, como também, para se inserirem nessas sociedades, e formarem e manterem caravanas atuantes que atravessassem o interior do continente, era necessário entender e seguir as normas sociais e hierárquicas locais. A partir de trocas de experiências conjuntas, nem sempre uniformes e pacíficas, essa comunidade foi desenvolvendo um protocolo de relações sociais para sobreviver e prosperar economicamente, em uma posição de subordinação política frente aos mandatários africanos. ${ }^{101}$

Nesse sentido, propomos entender os sertanejos como agentes específicos dentro de uma malha maior de atuação do comércio no interior

100 Miller, “Angola central e sul por volta de 1840”, pp. 26-29; Candido, “Os agentes não-europeus na comunidade mercantil de Benguela”, p. 114; Jill Rosemary Dias, “Angola” in Valentim Alexandre e Jill R. Dias (orgs.), O Império africano: 1825-1890 (Lisboa: Estampa, 1998), pp. 364-365.

101 Santos, Nos caminhos de África, p. 3; Margarido, “Algumas formas da hegemonia africana nas relações com os europeus”, pp. 398-399. 
que era a dos mambari. ${ }^{102}$ A formação de grandes comitivas, que precisavam de mais pessoas do que só os escravizados e dependentes diretos (quimbares) do chefe da caravana, exigia grande influência e recursos, que só eram acessíveis aos sertanejos e alguns comerciantes africanos mais ricos. ${ }^{103}$ São essas caravanas maiores que conseguiam chegar a regiões mais distantes como o Barotse para trazer marfim, tornando-se na década de 1860 as caravanas de maior interesse dos comerciantes de Benguela. ${ }^{104}$ No entanto, ao mesmo tempo, os agentes intermediários dessas caravanas, os pombeiros, com o trabalho nas caravanas, podiam acumular riquezas suficientes para fazer suas próprias expedições, em viagens mais curtas e com comitivas menores - trazendo principalmente cera, produzida a leste do Planalto, que se tornou o principal produto de exportação na alfândega de Benguela em meados do século. ${ }^{105}$ Esses pombeiros também utilizariam

102 Vale lembrar que os sertanejos do Bié também eram assim chamados no interior. Ver nota 92.

103 Uma das particularidades do comércio de longa distância no interior da atual Angola era que, com a ausência de rios navegáveis para longas rotas e a alta incidência de doenças para animais, principalmente contra o gado bovino, a opção mais viável para o comércio de longa distância era o recrutamento de carregadores humanos, cujo controle era concentrado nas mãos de mandatários ou de grandes comerciantes. Ver: Linda M. Heywood, "Porters, Trade and Power: The Politics of Labor in the Central Highlands of Angola, 1850-1914” in Catherine Coquery-Vidrovitch e Paul E. Lovejoy (orgs.), The Workers of African Trade (Beverly Hills: Sage Publications, 1985), pp. 243-246. Sobre a importância e agência dos carregadores dentro das caravanas da região de Angola, ver principalmente: Elaine Ribeiro da Silva dos Santos, "Sociabilidades em Trânsito: os carregadores do comércio de longa distância na Lunda (1880-1920)”, Tese (Doutorado em História), Universidade de São Paulo, São Paulo, 2016.

104 BPMP, ms. 1238, Viagens e apontamentos de um portuense em África, v. 3-BIS, fl. 26.

105 Isabel Castro Henriques, "Comércio e empresários em Angola na 2a. Metade do século XIX” in Isabel Castro Henriques, Os pilares da diferença: relações Portugal-África, séculos $X V-X X$ (Casal de Cambra: Caleidoscópio, 2004), pp. 399-400; Santos, "Perspectiva do Comércio Sertanejo do Bié na Segunda Metade do Século XIX", pp. 11-12; Biblioteca Pública Municipal de Porto (BPMP), Porto, ms. 1239, Silva Porto, Viagens e Apontamentos de Um Portuense em África, v. 4, 02 jan. 1868, fl. 263-264. Essa informação sobre a cera ser o principal produto de exportação em Benguela em meados do século XIX pode parecer contraditória com a afirmação da nota anterior de que as caravanas que traziam marfim eram as mais apreciadas pelos comerciantes do litoral. Na realidade, o valor individual das pontas de marfim era bastante superior ao pão de cera, unidade de cerca de 60 libras, sendo o marfim um produto preferencial para pagar as faturas do crédito que será descrito na sequência. 
os seus novos recursos para adquirirem títulos de nobreza e ascenderem como elites políticas, erodindo a esfera de influência dos grandes mandatários ao longo da segunda metade do século. ${ }^{106}$

Em Angola, tanto o marfim quanto a cera já eram exportados em quantidades consideráveis pelo menos desde o século XVII. Como eram negócios secundários perto do tráfico de escravizados, o comércio desses produtos do Bié para Benguela até a década de 1830 era restrito a negociantes africanos e a sertanejos mais pobres. ${ }^{107}$ No entanto, com a proibição legal do tráfico de escravizados em 1836, mesmo que não tenha interrompido o intenso contrabando que se manteve até o início dos anos 1860, os grandes traficantes de escravizados do litoral angolano passaram a financiar sertanejos para que trouxessem do interior gêneros coloniais como marfim e cera, na fase do chamado “comércio lícito”. Dessa forma, o sertanejo contraía um empréstimo com a casa comercial a ser pago com os ganhos da permuta no interior. Como não havia monetarização no interior do continente, a fatura inicial era realizada em gêneros, principalmente tecidos, bebidas alcóolicas, armas de fogo e pólvora, esperando-se que no retorno o sertanejo compensasse esse valor com principalmente o marfim e a cera que traziam do interior. ${ }^{108}$

De qualquer forma, as caravanas que iam mais longe também transportavam muita cera, já que no retorno das regiões produtoras de marfim podiam trocar os produtos importados excedentes por pães de cera vendidos no meio do caminho.

106 Heywood, Contested power in Angola, pp. 20-21.

107 Oppen, Terms of Trade and Terms of Trust, p. 63.

108 Dias, “Angola”, pp. 74-75; Roquinaldo Ferreira, Dos sertões ao Atlântico: tráfico ilegal de escravos e comércio lícito em Angola 1830-1860, Luanda: Kilombelombe, 2012, pp. 269-270. A grande diferença dos sertanejos frente aos outros mambari era de fato essa possibilidade de acessar esse crédito diretamente com as casas comerciais portuárias. Dessa forma, conseguiam investimentos iniciais que permitiam a formação das caravanas maiores que iam mais longe. Uma importante virada nessa correlação de forças foi em 1874, quando comerciantes africanos do Planalto passaram a conseguir crédito diretamente das casas comerciais, sem a necessidade de um intermediador luso-africano. Essa mudança se deveu ao aquecimento do negócio da borracha que, a partir daquela década, tornou-se a principal atividade econômica da região. Oppen, Terms of Trade and Terms of Trust, pp. 80-81. 
Para alcançar a máxima lucratividade do empreendimento, os sertanejos procuravam mandatários africanos poderosos como interlocutores principais. Quanto mais presas de marfim conseguissem comprar por viagem, maior era a lucratividade; caso contrário, as mercadorias vindas do litoral seriam trocadas por objetos de menor valor e, no pior dos cenários, não seriam trocadas. ${ }^{109}$ Por essa razão, a partir de meados da década de 1840, o Barotse foi tido pelos sertanejos do Bié como o Eldorado, sendo uma região de relativo isolamento comercial, grandes populações de elefantes e em que todas as presas de marfim caçadas no território eram de direito exclusivo do rei. ${ }^{110}$ A manutenção desse monopólio comercial, assim como disputas sucessórias dentro da linhagem reinante dos kololo, enfraqueceram o poder central, abrindo espaço para um crescente contrabando de marfim por parte das caravanas mambari, que compravam diretamente com os povos dominados, em especial na região do Mashukulumbwe. Na década de 1860, não só os mambari, mas também comerciantes vindos de Kasanje, da colônia do Cabo e da Costa Oriental (de Zanzibar e da Bisa), já participavam ativamente tanto das permutas com o soberano do país quanto das redes de contrabando. ${ }^{111}$

Para além da necessidade de buscar interlocutores africanos que permitissem as maiores permutas possíveis, a realização de um cálculo antecipado dos gastos operacionais das viagens em caravana

109 Santos, Nos caminhos de África, pp. 234-235.

110 Santos, Nos caminhos de África, p. 308. Isabel Castro Henriques chegou a afirmar que durante o período de atuação das grandes caravanas, o comércio era monopolista tanto para os europeus, quanto para os africanos. Consideramos essa afirmação exagerada. As situações nos Estados africanos são diversas, porém, no caso português, como já apontamos, mesmo que houvesse estruturas formais de monopólio comercial, a realidade de grande diversidade de trocas que desrespeitavam os projetos de domínio colonial sugere que muitas vezes esse monopólio português não passava de uma ficção política. Inclusive, acreditamos que o foco excessivo de parte da historiografia em função desses monopólios leva a interpretar uma grande diversidade de situações na chave conceitual de contrabando, dificultando, assim, a percepção das lógicas por trás das escolhas das autoridades africanas por um ou outro de seus interlocutores comerciais. Ver: Henriques, “Comércio e empresários em Angola na 2ª metade do século XIX”, p. 398.

111 Santos, Nos caminhos da África, p. 237; Hogan, “The Ends of Slavery in Barotseland”, p. 88; Santos, “Introdução”, pp. 117-121, 157-165. 
era fundamental para manter a lucratividade do empreendimento. Um dos principais gastos eram com impostos de passagem, as chamadas quibandas, geralmente pagas com fazendas (tecidos manufaturados) e bebidas alcóolicas, variando de valor de acordo com o poder do soba que cobrava o imposto no caminho em troca da passagem segura por suas terras. Também era comum que sobas enviassem emissários para os estabelecimentos dos sertanejos no Bié para pedirem presentes, ação que Silva Porto registra como comedorias, que eram pagas para evitar futuros conflitos nos caminhos das caravanas. Também havia o sistema de mucanos, termo utilizado para denominar tanto os crimes quanto as multas que os compensavam, sendo com frequência mobilizado esse aparato jurídico para acusar os sertanejos por crimes que eles ou seus dependentes haviam cometido, sendo importante instrumento de acumulação de riquezas. ${ }^{112}$ Mesmo com constantes reclamações em seus relatos escritos, os comerciantes do interior sabiam que tinham que cumprir esses gastos, devido à sua posição subalterna na sociedade local.

Uma pergunta relevante para refletirmos sobre o protagonismo africano no comércio interno é sobre o significado e importância das mercadorias importadas trazidas pelas caravanas. Tal questão, na prática, significa refletir sobre a própria importância da passagem de caravanas pelas terras dos mandatários africanos, tão valorizada na fala do soba Cutumbuca que abre essa seção. Uma pista pode estar numa reunião convocada por um dos membros do conselho dos anciãos do Bié, um macota, em que chamou os sertanejos residentes no reino por ocasião do coroamento de um novo soba:

112 Deolinda Barrocas e Maria de Jesus Souza, “As populações do hinterland de Benguela e a passagem das caravanas comerciais (1846-1860)”, II Reunião Internacional de História da África - A Dimensão Atlântica da África (São Paulo e Rio de Janeiro, 1997), pp. 95-107; SGL, res. 2 - C - 6, Viagens e apontamentos de um portuense em Africa, v. 2, fl. 12, 28 nov. 1860; Margarido, "Algumas formas da hegemonia africana nas relações com os europeus”, p. 398. Para mais sobre o funcionamento do sistema de mucanos, ver: Roquinaldo Ferreira, Cross-cultural Exchange in the Atlantic World: Angola and Brazil During the Era of the Slave Trade, Nova York: Cambridge University Press, 2012, pp. 88-125. 
Senhor Capitão Mor, e mais senhores. Eis ali o vosso filho [o novo soba do Bié], tratai-o bem para que viva longos anos; tendo muito cuidado com a aguardente que mandais para a libata grande [fortaleza do soba] [...]. Ora, o soba não o pode já mais ser, sem a vossa coadjuvação, para esse fim, e para a sua total ascensão ao poder, preciso lhe é o vosso apoio; nós, pela nossa parte nada temos, porque como sabeis, somos também do número dos vossos filhos; e então, finalmente, passo a fazer contribuintes para as despesas do soba no estado [...]. Assim pois, senhores, espero que atendereis ao que acabou de vos expor, ficando por esta forma encerrada a atual sessão, até ulterior ordem do vosso filho; do vosso amigo e soba de nós todos, para a sua definitiva posse; para a qual sem dúvida também sereis convidados. ${ }^{113}$

A fala do macota, mesmo sendo preâmbulo para a cobrança de mercadorias para o novo soberano, não só mostra o lugar fundamental dos sertanejos como os fornecedores de bebidas alcoólicas para o soba, mas também como base da sua ascensão e manutenção do poder. Esse grande interesse dos mandatários africanos pelas mercadorias sertanejas provoca por vezes comentários sarcásticos de Silva Porto, como quando se refere ao soba de Cangilla como seu amigo, ou melhor, “amigo de sua fazenda”, pois o soba e seus dependentes visitam o estabelecimento do sertanejo e ficam à espera da chegada de carregamento de fazendas para as comedorias. ${ }^{114}$ Joseph Miller defende que há uma relação espiral de como a demanda por gêneros importados ao longo dos séculos de tráfico atlântico reforçou graus crescentes de subordinação e dependência das grandes autoridades africanas e de seus súditos frente aos negociantes atlânticos, já que esses produtos eram instrumentos importantes para o seu exercício do poder. ${ }^{115}$

113 SGL, res. 2 - C - 6, Viagens e apontamentos de um portuense em África, v. 2, fl. 126-127, 22 maio 1861.

114 SGL, res. 2 - C - 6, Viagens e apontamentos de um portuense em África, v. 2, fl. 144, 4 jul. 1861.

115 Miller, Way of Death, pp. 152-153. 
A conexão dessas regiões por séculos pelo comércio com o Atlântico consolidou demandas específicas por produtos importados, geralmente variando de região para região. Não se pode entender, no entanto, que essas demandas foram imposições de valores europeus sobre os povos africanos - muito mais do que isso, esses produtos dependiam da aceitação ou não do seu valor como viáveis para troca pelos mandatários africanos, geralmente ocupando funções análogas a produtos que já circulavam nas rotas regionais e de longa distância preexistentes (como o caso de tecidos, bebidas alcóolicas e contarias). ${ }^{116}$ Assim, os comerciantes tinham que aprender as demandas específicas de produtos de cada região, necessitando para a sua atividade comercial uma diversidade enorme de produtos, para presentes e venda no interior - caso das fazendas, aguardente, pólvora, contarias, escravizados, enxadas de ferro, tabaco, sal, missangas, corais, gado, alimentos, entre outros. Muitos desses produtos tinham funções como bens de prestígio no interior das sociedades africanas, sendo monopólios das elites dominantes; outros tinham função mais generalizada, sendo acumulados para permutas individuais com caravanas que passassem pelas terras. Muitos dos produtos inclusive não tinham origem atlântica, sendo comprados no meio do caminho para cumprirem papeis específicos para permitir a chegada dos carregamentos de marfim e cera no litoral. ${ }^{117}$

116 Márcia Cristina Pacito Fonseca de Almeida, “Comércio, bens de prestígio e insígnias de poder: as agências centro-ocidentais africanas nos relatos de viagem de Henrique de Carvalho em sua expedição à Lunda (1884-1888)”, Dissertação (Mestrado em História), Universidade de São Paulo, São Paulo, 2015, pp. 130-132 ש.

117 Santos, Nos caminhos da África, p. 240; Almeida, “Comércio, bens de prestígio e insígnias de poder”, pp. 154-159, 171-177, 191-192. Para ilustrar essa diversidade, há entre os cadernos de Silva Porto o seu livro de cargas, no qual anotava as cargas sob responsabilidade de cada carregador de uma expedição. No caso de uma viagem de Benguela para o Bié em 1879, Silva Porto registra nas cargas os seguintes produtos: fazendas (de vários tipos e cores), missangas de várias cores, roupas, contaria, armas de fogo, pólvora, vinho, aguardente, sal, café, açúcar, arroz, farinha de trigo, azeite, tinta, conservas, peixe seco, velas, chumbo, vinagre, queijos, manteiga, arame, sabão, rede, adriça, talheres, vasilhas e pratos, além de "miudezas" que não especifica. Ver: SGL, res. 2 - B - 31, António Francisco Ferreira da Silva Porto, Livro de cargas, 1879-1889. 
Tendo em vista esse interesse pelos produtos transportados pelas caravanas da zona atlântica, Margarido entende que os impostos de passagem, cobrança de mucanos e os pedidos de dádivas eram estratégias de mandatários do meio do caminho de tentar reter consigo parte das mercadorias que iam em direção ao interior. ${ }^{118}$ A sua hipótese parece bastante razoável ao considerarmos a supracitada demanda de agentes envolvidos no comércio por comprar títulos de nobreza. Não sendo pertencentes às linhagens reinantes, ao se tornarem sekulus (chefes de aldeia), esses sujeitos ganhavam a prerrogativa de cobrarem a passagem e acusarem mucanos, além de controlar passagens de rios, seja na cobrança de serviço de frete de canoas, seja na construção de pontes pelas quais cobravam pedágios. ${ }^{119}$

No entanto, Margarido vai mais além no seu raciocínio. Temendo o avanço crescente de caravanas portuguesas por terras cada vez mais ao interior, para o autor, os esforços dos mandatários de reter produtos importados no caminho não se resumiam à valorização de tais produtos no interior do continente, e sim a uma tentativa de frear o avanço do comércio europeu para assim manter a hegemonia africana sobre o interior. ${ }^{120}$ É interessante destacar uma citação que Margarido usa para justificar a sua tese, reproduzindo do relato de Joaquim Rodrigues Graça, comerciante que viaja para a Lunda na década de 1840, uma fala do soberano do império Lunda, o Muatiânvua: "Que é que me quer o Muene Puto de Luanda? ${ }^{121}$ Procura-me negócios; ele precisa de mim... eu não preciso dele, pois que de minhas terras é que lhe vai a cera”. ${ }^{122}$ Mesmo sendo importante a consideração de Beatrix Heintze de que, com o crescimento da importância da circulação de informações para as dinâmicas político-econômicas do

118 Margarido, "Algumas formas da hegemonia africana nas relações com os europeus”, p. 396.

119 Candido, Fronteras de esclavización, p. 72; Heywood, Contested Power in Angola, p. 16.

120 Margarido, "Algumas formas da hegemonia africana nas relações com os europeus”, p. 398.

121 Muene Puto é como chamavam o rei de Portugal no interior de Angola.

122 Rodrigues Graça, [1846] 1890 apud Margarido, “Algumas formas da hegemonia africana nas relações com os europeus”, p. 396. 
interior, as informações dadas em audiências públicas aos viajantes eram geralmente vagas e rituais, sendo feita a realpolitik em reuniões reservadas e secretas, o relativo menosprezo do Muatiânvua com os comerciantes caravaneiros contrasta com a importância das caravanas destacada por vários mandatários africanos durante a passagem das comitivas de Silva Porto, tendo sido alguns desses episódios já referidos nesse texto. ${ }^{123}$

Isabel Castro Henriques propõe uma interpretação mais processual do significado das atitudes dos mandatários africanos frente às caravanas vindas do Atlântico. Mais do que uma recusa consciente do avanço do comércio atlântico, Henriques entende as estratégias dos mandatários como tentativas de manutenção do controle em um momento de transformação da noção de riqueza no interior do continente. Até então sendo associada ao número de dependentes, a riqueza seria crescentemente relacionada à posse de mercadorias e, posteriormente, de dinheiro, por causa da generalização da atividade comercial para diversos sujeitos na fase do comércio lícito. Segundo a autora, isso demonstraria, acima de tudo, uma grande capacidade dos sistemas sociais africanos de se adaptarem aos valores e práticas da modernidade comercial. ${ }^{124}$

Portanto, para Henriques, as mudanças na organização das caravanas, menores, mais ágeis e comandadas por negociantes africanos, a generalização do acesso ao crédito das casas comerciais litorâneas, a crescente concorrência aberta por uma gama crescente de novos negociantes e a proliferação de centros comerciais geridos por africanos no interior eram todos sintomas da racionalização do comércio africano, adaptando-se às novas demandas do capitalismo industrial. ${ }^{125} \mathrm{O}$ dinamismo, flexibilidade, vontade e capacidade de modernização das sociedades africanas ficariam

123 Beatrix Heintze, A África centro-ocidental no século XIX (c. 1850-1890): intercâmbio com o mundo exterior - apropriação, exploração e documentação, Luanda: Kilombelombe, 2013, p. 205; Margarido, “Algumas formas da hegemonia africana nas relações com os europeus”, p. 399.

124 Henriques, “Comércio e empresários em Angola”, pp. 395-398. Sobre os impactos dessa mudança do sentido de riqueza, ver pp. 408-411.

125 Henriques, “Comércio e empresários em Angola”, pp. 399-402. 
expostos pela ação desses agentes, na sua maioria africanos, que passaram a comandar as redes do comércio interno na segunda metade do século XIX, atuando como agentes de transformação, ou de modernidade. ${ }^{126}$

No Planalto Central, esses vários agentes de transformação formavam a rede diversificada dos mambari. Recapitulando a nossa proposta, não só os sertanejos e seus pombeiros formaram rotas distantes e permitiram a ascensão social de membros das suas caravanas, mas além deles muitos comerciantes africanos, inicialmente dedicados ao comércio da cera, e após a década de 1870 ao da borracha, aprofundaram o processo de ascensão social pela carreira comercial e de erosão do poder dos sobas, o que em último caso favoreceria a ocupação militar portuguesa da região na virada do século. ${ }^{127}$ A própria Henriques destaca o enorme fosso entre os interesses dos comerciantes europeus e os dos mandatários africanos, mas não se pode assumir como certo e previsível o desenrolar desse processo várias décadas antes da conquista - a realidade é que, no auge do comércio lícito, eram os mandatários africanos que, via de regra, dominavam os termos das trocas e também eram africanos os principais agentes comerciais do interior. ${ }^{128}$

Consideramos ser mais interessante para compreender as atitudes dos mandatários africanos e dos agentes comerciais em geral seguir a proposta interpretativa de Oppen. Mais do que essencializar as escolhas de portugueses ou africanos por explicações mais generalizadas e estruturais, esse historiador propõe pensar as relações sociais envolvidas no cotidiano do comércio como contínuas confirmações e renegociações dos termos das trocas entre as partes envolvidas, sendo produto de constantes disputas por poder e recursos. Assim, as diferentes atitudes de autoridades africanas, desde aquelas que proibiam a passagem de caravanas, cobravam impostos e gastos suplementares, até aquelas que pediam para os sertanejos construírem estabelecimentos em suas terras, devem ser entendidas

126 Henriques, “Comércio e empresários em Angola”, pp. 403, 407.

127 Heywood, Contested Power in Angola, pp. 19-20.

128 Henriques, “Comércio e empresários em Angola”, p. 396. 
como resultado de interações históricas locais e regionais, e não como expressões de estruturas lógicas estanques. ${ }^{129}$

Assim, procuramos demonstrar que a reorientação das demandas do comércio atlântico para Angola, passando a solicitar gêneros coloniais no lugar de escravizados para as Américas, gerou profundas transformações no interior da zona atlântica angolana, o que seria esperado da região que foi a principal origem de escravizados para o Novo Mundo durante a Era Moderna. No entanto, mesmo estando essas conexões atlânticas sob controle direto dos agentes comerciais residentes na colônia portuguesa do litoral, os termos das trocas das maiorias dos produtos que lá chegavam eram controlados pelas autoridades africanas autônomas, que não dominavam só as regiões produtoras, mas também os caminhos, forçando os comerciantes, fossem eles europeus ou africanos, a respeitarem o exercício de seu poder. Em último caso, vale a constatação de Henriques que determina claramente a dependência do comércio angolano, e - por que não dizer - das redes atlânticas conectadas a ele, frente aos agentes africanos:

Com efeito, quem os poderia ter obrigado [aos africanos] a produzir a borracha, ou a aumentar o volume de marfim produzido, ou a identificar e a colher a urzela? Os europeus não dispunham dos meios de coerção permitindo que tais operações fossem levadas a cabo. As decisões pertencem por isso às organizações sociais africanas. ${ }^{130}$

É notório que esse sistema social africano entraria em crise por causa do mesmo processo econômico, já que a generalização da concorrência e multiplicação dos agentes comerciais seriam fatores de desestabilização tanto do comércio sertanejo, quanto da centralização política dos mandatários. ${ }^{131}$ Também é verdade que, mesmo no período anterior, durante o auge do tráfico transatlântico de escravizados, a generalização da violência das

129 Oppen, Terms of Trade and Terms of Trust, pp. 22-23.

130 Henriques, “Comércio e empresários em Angola”, p. 396.

131 Santos, “Introdução”, pp. 97-98; Heywood, Contested Power in Angola, pp. 1-30. 
razias, a ascensão política dos chefes guerreiros e a difusão de grupos de refugiados e de epidemias foram consequências socialmente disruptivas que se somavam à perda populacional de milhões de homens e mulheres, com efeitos nefastos para a história das sociedades da zona atlântica. ${ }^{132}$ Mas é necessário apontar que, algumas décadas antes da conquista portuguesa do interior de Angola, são esses mandatários que se fortaleceram com as vultuosas quantidades de mercadorias importadas do Atlântico, trazidas por numerosas caravanas que controlavam o acesso aos gêneros coloniais crescentemente demandados no exterior.

\section{Considerações finais}

A partir da comparação que propomos nesse artigo entre duas zonas tão distintas, tanto no tempo quanto no espaço, pudemos mensurar o impacto das conexões atlânticas ao percebermos algumas importantes similaridades entre os processos históricos ocorridos na Senegâmbia nos séculos XVI e XVII e no Planalto Central angolano no século XIX. A primeira é o fato de que os portos atlânticos eram sim elementos constitutivos e transformadores para o comércio realizado em África. Porém, definitivamente, não eram polos comerciais isolados em relação ao interior do continente. Ao contrário, mesmo após o advento do comércio atlântico no caso da Senegâmbia ou nos princípios da colonização do interior de Angola, o comércio interno ao continente era de extrema relevância para os povos locais e mantinha linhas de funcionamento autônomo.

Evidentemente, a presença europeia e o comércio atlântico mudaram consideravelmente as estruturas políticas, sociais, culturais e

132 Miller, Way of Death, pp. 153-167; Candido, An African Slaving Port and the Atlantic World, p. 296. Para um instigante ensaio comparativo sobre os impactos do comércio de longa distância na África durante a Era Morderna com a Europa, ver: Olivier Pétré-Grenouilleau, "Long-Distance Trade and Economic Development in Europe and Black Africa (Mid-Fifteenth Century to Nineteenth Century): Some Pointers for Further Comparative Studies”, African Economic History, v. 29, (2011), pp. 163-196. 
econômicas na África. Um novo nicho comercial se abriu e o processo de hemorragia demográfica causada pelo comércio transatlântico de pessoas abriu uma ferida que nunca se cicatrizou. Porém, perspectivas que abordaram essas histórias pela perspectiva de “impérios” - denotando um poder político e econômico europeu, em sentido coercitivo ou impositivo, em África anterior ao século XIX - são, no mínimo, exageradas. Consideramos que tais perspectivas, para além de por vezes superestimarem a interferência política europeia nessas regiões, privilegiaram o destaque a sujeitos específicos das redes comerciais, principalmente os ditos euro-africanos, apagando muitos agentes fundamentais dessas redes que vivenciaram na realidade várias diásporas comerciais simultâneas, não só aquelas relacionadas à presença europeia.

Além disso, percebemos nos dois estudos de caso que o comércio por vias atlânticas não se concentrava apenas no infame tráfico de pessoas para o Atlântico. Não ressaltamos este aspecto para retirar o peso social, político e econômico da escravidão, ainda mais em regiões que foram tão fortemente afetadas pelo tráfico de escravizados. Pensamos ser importante, porém, entender como outras dinâmicas estavam relacionadas ou mesmo se mantinham independentes desse fluxo, o que facilita nossa compreensão do comércio africano para além do fornecimento de pessoas para uma inesgotável demanda atlântica. Existe uma infinidade de dimensões no comércio realizado na África, dimensões estas que vão muito além da esfera de atuação dos esparsos enclaves comerciais europeus no litoral.

Nesse sentido, análises regionalizadas, procurando entender as especificidades do continente africano em relação ao mundo atlântico, são uma necessidade imediata para a produção historiográfica africanista, como no caso dos estudos macrorregionais sobre comércio interno. Pensamos que são justamente estes estudos específicos sobre o continente africano que nos permitirão entender mais profundamente as dimensões locais que fogem das explicações tradicionais, que se tornam eurocentradas no sentido de sempre procurar entender a presença das diversas nações europeias em África, e não a autonomia histórica das regiões 
focalizadas. Além disso, são esses estudos localizados que possibilitarão a ampliação do entendimento, bem como a busca por similaridades e diferenças, no que tange aos processos globais que conectaram as diversas macrorregiões africanas ao restante do mundo; foi com este horizonte que tentamos, de alguma forma, propor este artigo.

Recebido em 15 maio 2020

Aprovado em 27 out. 2020

doi: 10.9771/aa.v0i62.36848 
Este artigo tem por intenção discutir o funcionamento do comércio de longa distância no interior de duas regiões que foram profundamente integradas às malhas do comércio atlântico, a Senegâmbia e a Angola Central, em dois momentos de reconfiguração econômica dessas macrorregiões: a intensificação do contato dos povos da Senegâmbia com o comércio atlântico nos séculos XVI e XVII e as novas demandas por gêneros coloniais de Angola em meados do XIX, após a proibição legal do tráfico de escravizados. Para isso, analisamos as dinâmicas sociais e econômicas preexistentes nas regiões, os agentes comerciais envolvidos neste comércio, bem como a circulação de mercadorias atlânticas, debatendo por fim sobre as transformações políticas, sociais e econômicas causadas por esses processos históricos.

Comércio atlântico | Agência | Senegâmbia | Planalto Central angolano

\section{Between Senegambia and Angola:}

\section{Atlantic Commerce, African Progatonism and Regional Dynamics}

This article discusses the operation of long distance trade within two regions that have been deeply integrated into networks of Atlantic commerce, Senegambia and Central Angola, during two periods when these macro-regions were undergoing economic reconfiguration: the intensification of contact by Senegambian peoples with Atlantic trade in the 16th and 17th centuries, and the new demands for colonial goods from Angola in the mid-1800s, after the legal prohibition of the slave trade. Thus, we analyze the preexisting social and economic dynamics in the regions, the commercial agents, and the circulation of Atlantic goods, debating the political, social and economic transformations caused by these historical processes.

Atlantic commerce | Agency | Senegambia | Angolan Central Highlands 